\title{
Organic Matter Decomposition and Ecosystem Metabolism as Tools to Assess the Functional Integrity of Streams and Rivers-A Systematic Review
}

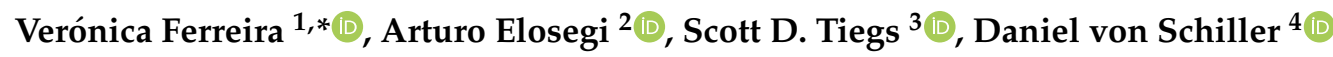 \\ and Roger Young ${ }^{5}$ \\ 1 Marine and Environmental Sciences Centre-MARE, Department of Life Sciences, University of Coimbra, \\ 3000-456 Coimbra, Portugal \\ 2 Faculty of Science and Technology, University of the Basque Country (UPV/EHU), P.O. Box 644, \\ 48080 Bilbao, Spain; arturo.elosegi@ehu.eus \\ 3 Department of Biological Sciences, Oakland University, Rochester, MI 48309, USA; tiegs@oakland.edu \\ 4 Department of Evolutionary Biology, Ecology and Environmental Sciences, Institut de Recerca de \\ l'Aigua (IdRA), University of Barcelona, Diagonal 643, 08028 Barcelona, Spain; d.vonschiller@ub.edu \\ 5 Cawthron Institute, Private Bag 2, Nelson 7042, New Zealand; roger.young@cawthron.org.nz \\ * Correspondence: veronica@ci.uc.pt
}

Received: 4 November 2020; Accepted: 8 December 2020; Published: 15 December 2020

\begin{abstract}
Streams and rivers provide important services to humans, and therefore, their ecological integrity should be a societal goal. Although ecological integrity encompasses structural and functional integrity, stream bioassessment rarely considers ecosystem functioning. Organic matter decomposition and ecosystem metabolism are prime candidate indicators of stream functional integrity, and here we review each of these functions, the methods used for their determination, and their strengths and limitations for bioassessment. We also provide a systematic review of studies that have addressed organic matter decomposition (88 studies) and ecosystem metabolism (50 studies) for stream bioassessment since the year 2000. Most studies were conducted in temperate regions. Bioassessment based on organic matter decomposition mostly used leaf litter in coarse-mesh bags, but fine-mesh bags were also common, and cotton strips and wood were frequent in New Zealand. Ecosystem metabolism was most often based on the open-channel method and used a single-station approach. Organic matter decomposition and ecosystem metabolism performed well at detecting environmental change $(\approx 75 \%$ studies), with performances varying between 50 and 100\% depending on the type of environmental change; both functions were sensitive to restoration practices in $100 \%$ of the studies examined. Finally, we provide examples where functional tools are used to complement the assessments of stream ecological integrity. With this review, we hope to facilitate the widespread incorporation of ecosystem processes into bioassessment programs with the broader aim of more effectively managing stream and river ecosystems.
\end{abstract}

Keywords: cotton strip assay; ecosystem functioning; ecosystem respiration; gross primary production; leaf litter; methods; stream health; net ecosystem productivity; systematic map; wood

\section{Stream Ecological Integrity and Functional Indicators}

Like all ecosystems, streams and rivers can be characterized by both their structure and function. Ecosystem structure refers to the physical characteristics of the ecosystem (e.g., water quality and channel form) and the composition of biological communities, while ecosystem functioning refers to the processes, such as those that control energy and matter fluxes in the ecosystem, including organic matter decomposition and ecosystem metabolism [1]. The European Water Framework Directive 
recognizes that "ecological status is an expression of the quality of the structure and functioning of aquatic ecosystems associated with surface waters," but it only considers structural elements for the evaluation of the ecological status of streams and rivers: biological elements (aquatic flora, benthic invertebrates, fish), hydromorphological elements (hydrological regime, river continuity, channel morphology), chemical and physical elements (nutrients, $\mathrm{pH}$ ), and specific pollutants (Directive 2000/60/EC [2]). Similarly, assessments in the United States focus on invertebrates, water quality parameters, and geomorphological classifications [3]. Since ecological integrity includes both structural and functional integrity, bioassessment of streams and rivers focusing solely on structural elements provides an incomplete and potentially misleading picture of the overall ecological integrity. This is of concern because structure and function can respond differently to environmental change [4-6], and there can be alterations in functioning (e.g., organic matter decomposition) without noticeable alterations in structure (e.g., benthic invertebrate community composition) [7,8]. Additionally, ecosystem functions are closely linked to the ecosystem services upon which human societies depend $[9,10]$, and therefore, evaluating ecosystem functioning is critical to understanding impacts on ecosystem services. The recent New Zealand National Policy Statement for Freshwater Management 2020 reflects this need and recognizes ecosystem health as a compulsory value to be protected, noting that it specifically incorporates five elements: water quality, water quantity, physical habitat, aquatic life, and importantly, ecosystem function [11].

Many biologically mediated ecosystem functions can potentially be used in stream bioassessment [12]. Here, we focus on two processes for which there is significant background information on their sensitivity to environmental stressors and that have been most often studied in the context of stream bioassessment: organic matter decomposition and ecosystem metabolism [1,13]. Organic matter decomposition connects riparian vegetation and aquatic communities via the instream cycling of energy and nutrients of terrestrial origin, while ecosystem metabolism is an integrative measure of organic carbon production and consumption. Both functions integrate environmental conditions over time, and across multiple trophic levels and multiple levels of biological organization, such that changes in a single level may be reflected in altered process rates [1,13]. Additionally, both organic matter decomposition and ecosystem metabolism are partly carried out by organisms that are not usually considered in bioassessment, namely, heterotrophic microorganisms, and these functions can therefore reflect changes in the microbial community structure and activity that are not detected in standard bioassessment programs. Furthermore, organic matter decomposition and ecosystem metabolism do not depend on the presence of a specific taxon, but rather on functional groups (e.g., invertebrate shredders), potentially allowing for large spatial scale comparisons that are not complicated by biogeography [10]. However, these functions will only be useful bioassessment tools if they respond predictably and sensitively to environmental change and anthropogenic stressors and can discriminate between different types of human impacts [14].

\section{Organic Matter Decomposition}

\subsection{Phases and Key Players}

Organic matter decomposition has been conceptualized as having three interdependent phases, which can overlap in time: (I) leaching, (II) microbial conditioning, and (III) fragmentation by invertebrates and physical abrasion [15]. The leaching of soluble compounds occurs mostly during the first days of immersion, but it can last for weeks [16-18]. The rate of litter mass loss via leaching and the duration of this phase depend on litter characteristics, which vary with litter type (e.g., leaves vs. wood), leaf species, and leaf condition (e.g., green vs. senescent, fresh vs. dried) [16,18-21]. Although leaching is generally more intense for dried than fresh leaves, and microbial colonization may be stimulated in dried leaves, colonization by macroinvertebrates and overall decomposition rates do not seem to be affected by the leaf condition [16,22,23], and air-dried litter is commonly used in litter decomposition experiments. Environmental conditions can also influence leaching, which tends to be greater at 
warmer temperatures [24]. Overall, leaching can lead to the loss of up to $33 \%$ of the initial mass of dried leaves [20].

Microbial conditioning results from the colonization of organic matter by microbial decomposers and their subsequent activities, especially after secondary compounds with antimicrobial activity have been leached out of the leaves [25]. Among aquatic microbes, fungi (aquatic hyphomycetes in particular) are regarded as the main litter decomposers, especially during the initial stages of litter decomposition, contributing up to $66 \%$ to litter mass loss in fine-mesh bags [26,27]. Litter decomposition rates are often correlated with aquatic hyphomycete biomass and sporulation rates $[25,28-30]$. Bacteria become more important in the latter stages of litter decomposition, but their contribution to microbially driven litter mass loss is generally low (up to $14 \%[27,31]$ ). Less information is available on the roles of yeasts, zoosporic fungi, oomycetes, and protists, but they were found to be associated with decomposing leaf litter and can affect litter decomposition directly or indirectly via trophic interactions [32-36]. The role of algae on litter decomposition is also uncertain with some studies suggesting that they can stimulate litter decomposition via microbial priming (i.e., the stimulation of microbial decomposers' activity by the addition of labile carbon) [37], while other studies found inhibition or no effect $[38,39]$. Microbial activity leads to litter mass loss through the release of fine particles and dissolved litter mass, incorporation of litter carbon into microbial biomass (including reproductive structures that are released), and carbon mineralization [40-42]. Lastly, conditioning also promotes shredder colonization and activity by the accumulation of nutrient-rich fungal biomass, which reduces litter carbon:nutrient ratios, and litter softening [43].

Shredders are the invertebrate group this is most directly involved in litter fragmentation, and positive relationships between litter decomposition and shredder biomass and density are often found [29,44-46]. Shredders cause litter mass loss via feeding, using litter on their protective cases (such as those of case-building caddisflies), and by releasing litter fragments during feeding [31,47]. Invertebrate activity on litter can be responsible for up to $64 \%$ of leaf litter mass loss [31]. There are, however, streams where shredders are naturally rare or absent (e.g., some tropical or insular streams) and where litter decomposition is mostly microbially driven [48-50]. The contribution of invertebrate activity to mass loss cannot, generally, be isolated from that caused by physical abrasion by current and sediments. When litter is incubated concurrently at places with distinct current velocities, litter mass loss is often greatest at a high current velocity [51,52].

\subsection{Major Moderators and Sensitivity to Environmental Change}

Besides the characteristics of the biological players on litter decomposition (e.g., the biomass of aquatic hyphomycetes, the density of shredders; Section 2.1), the rate at which litter decomposition proceeds also depends on litter characteristics and environmental variables, which can vary as a result of human activities. Leaf species differ in their physical and chemical characteristics [53,54]. Moreover, intraspecific differences in litter characteristics can originate from differences in growing conditions or genotypes [55-58], and whether trees have been exposed to herbivory or infection by pathogens [59-61]. Additionally, within-tree variation in litter characteristics can stem from factors such as whether the leaves are "sun" or "shade" leaves [62,63]. Litter characteristics are a major determinant of litter decomposition, and soft leaves with high concentrations of nutrients and low concentrations of structural and secondary compounds decompose faster than more recalcitrant leaves $[53,54,56]$. Leaves also decompose faster than wood due to their softness and lower carbon:nutrient ratios $[29,64,65]$. Since microbial decomposers can obtain nutrients from the water column [42], and water-soluble secondary compounds (e.g., polyphenols) leach rapidly from leaf litter [17], the concentration of structural compounds (e.g., lignin) is often the prime determinant of litter decomposition rates $[28,54,66,67]$. Therefore, forest changes, such as the replacement of diverse native forests with plantations or their invasion by alien species, when accompanied by decreases in the diversity of litter inputs or by alterations in the litter trait frequency, may affect the instream litter decomposition [30,68-71]. 
The carbon:nutrient ratios of microbial biomass [72] are generally lower than those of litter [53,54], which generally makes decomposer activity on organic substrates nutrient-limited. However, microbes can take up nutrients from the water column to provide their nutritional needs [42,73]. Microbes are therefore highly sensitive to the availability of dissolved nutrients, and higher microbial activities and litter decompositions are generally found in streams with moderate nutrient concentrations relative to streams with low nutrient concentrations $[42,74,75]$. Thus, increases in the stream nutrient concentration due to, e.g., agricultural activities or atmospheric nitrogen deposition, may stimulate litter decomposition in streams [76,77]. Nutrient enrichment stimulates litter decomposition, especially when background nutrient concentrations are low and when the enrichment is high [78]. However, the stimulatory effects of nutrient enrichment may not be found when background nutrient concentrations are not limiting [73], when nutrient enrichment reaches toxic levels (e.g., high ammonia concentrations [79]), or when increases in nutrient concentrations are accompanied by changes in other environmental variables with inhibitory effects on litter decomposition (e.g., decreases in dissolved oxygen (DO) concentrations, increases in sedimentation [27,80]). Therefore, when considering large nutrient gradients, a hump-shaped relationship is often found between litter decomposition rates and nutrient concentration [80]. The stimulatory effects of nutrient enrichment on litter decomposition may be stronger for litter with low nutrient concentrations $[42,77]$ and weaker for litter with high concentrations of low-quality carbon (e.g., lignin [54]). Furthermore, the stimulatory effects of nutrient enrichment on microbial activity are generally increased by invertebrate activity, and thus, the overall litter decomposition may be more sensitive to nutrient enrichment than microbially driven litter decomposition $[77,80]$.

Water temperature controls all biological activities [81]. Microbial activities are generally stimulated in warmer conditions, which results in faster litter decomposition in warmer than colder seasons [51,82], at lower rather than higher elevations $[83,84]$, and at lower rather than higher latitudes $[85,86]$. However, if cold-water shredder abundance increases with elevation or latitude, overall litter decomposition may not differ between cooler and warmer streams [85,87]. Increases in water temperature resulting from human activities (e.g., thermal pollution, removal of riparian vegetation, urbanization) may stimulate litter decomposition, especially in colder seasons [88]. The effects of warming may depend on litter quality $[89,90]$. Furthermore, if warming severely decreases the oxygen solubility, litter decomposition may be inhibited [91]. Since many shredder species have evolved in cold waters, increases in temperature may not stimulate shredder activity [47,92].

Water $\mathrm{pH}$ naturally varies with geology and has been shown to control aquatic hyphomycete species richness (positive relationship in the range of $\approx 6$ to $\approx 8 \mathrm{pH}$ units [93-95]), and macroinvertebrate species richness (positive relationship in the range of $\approx 5$ to $\approx 6.5 \mathrm{pH}$ units [96]). Anthropogenic acidification (e.g., atmospheric acid deposition) thus results in reduced aquatic hyphomycete and macroinvertebrate species richness, and reduced shredder biomass, especially of efficient gammarid shredders [44,96,97]. Consequently, litter decomposition is inhibited in acidified streams with linear relationships found between litter decomposition rates and indicators of acidity $[44,98,99]$.

Current velocity varies within and between streams, and also over time, contributing to the variability in litter decomposition rates [52]. Litter decomposition is promoted by higher current velocity, especially at later stages when leaves are macerated and more prone to physical fragmentation $[51,52,100]$. A high current velocity may also promote leaf decomposition by stimulating microbial activity via an enhanced supply of oxygen and nutrients and the removal of leachates [101]. Therefore, anthropogenic changes to flow regimes have the potential to alter litter decomposition rates. Furthermore, litter decomposition slows significantly in the dry channels and isolated pools of intermittent streams [102-104]. Even after the flow resumes, litter decomposition can still be slower in intermittent streams than in perennial streams [105].

Anthropogenic activities generally lead to simultaneous changes in multiple environmental variables, which may have contrasting effects on aquatic communities and litter decomposition. For instance, forestry, agriculture, urbanization, industry, and mining can lead to changes in the 
following environmental variables, the magnitude and direction of the change depending on the type, and the extent and intensity of human activities: riparian vegetation cover and diversity, litter inputs, solar irradiation, water temperature, DO concentration, water flow, channel form, sedimentation, and nutrient concentrations [76,106-110]. Some activities can also result in the input of pharmaceuticals, pesticides, heavy metals, and organic pollution, which are generally not present in streams in the absence of human activities. Many of these human activities may co-occur in the same catchment $[29,82,111-113]$. These simultaneous environmental changes may affect litter decomposition in the same direction (synergistic effects). For instance, increases in heavy metals and acidification as a result of acid mine drainage can inhibit litter decomposition [114], while increases in nutrient concentration and warming stimulate it $[115,116]$. However, multiple stressors may also have contrasting effects on litter decomposition (antagonistic effects). For instance, the stimulatory effects of increases in nutrient concentrations may counteract the inhibitory effects of increases in fine sediment inputs on litter decomposition [76], and low oxygen concentration may counteract the stimulatory effects of increases in nutrient concentrations [27]. The magnitude and direction of changes in litter decomposition in the presence of multiple stressors are therefore more difficult to predict.

\subsection{Practicability of Organic Matter Decomposition as a Bioassessment Tool: Methods, Strengths, and Limitations}

Organic matter decomposition has potential as a useful component of bioassessment programs and as an informative complement to structural measures [1]. Foremost among the reasons for its use in bioassessment, organic matter decomposition is sensitive to environmental changes resulting from human activities, where the effects of these changes are generally predictable (Section 2.2). Furthermore, decomposition rates integrate the activities of phylogenetically diverse taxa, including bacteria, fungi, and macroinvertebrates, yet because its use in bioassessment is based on the quantification of an ecosystem function, no taxonomic expertise is required. Methodologically, litter decomposition is straightforward to quantify, inexpensive (although the most commonly applied approach, namely, the leaf litter bag assay, may require a substantial investment in time to collect and process leaves and make litter bags), easy-to-use, and requires no specialized equipment other than a balance, an oven, and a muffle furnace. These and other advantages have led to compelling calls for incorporating litter decomposition into bioassessment programs $[1,10,30]$. However, before such widespread incorporation can occur, several practical issues need to be addressed, notably, standardizing the litter quality and considering sources of natural variability in decomposition rates.

Stream bioassessment often relies on making comparisons with other sites (e.g., reference sites) or on tracking sites through time in order to evaluate ecosystem integrity. These comparisons are enabled via the standardization of methods because when they are used, differences between field sites or sampling dates can unequivocally be attributed to differences in environmental conditions. Standardizing most aspects of the leaf litter bag assay (for instance, litter bag mesh size and litter mass) is easy; standardizing leaf litter quality is more challenging. Litter quality is highly variable in ways that influence decomposition (Section 2.2). For instance, interspecific variation in the concentrations of nutrients and secondary compounds can result in decomposition rates that vary by orders of magnitude [53,117]. A seemingly easy solution is the use of a single plant species in bioassessment procedures [1]. Complicating this approach, however, is the intraspecific and even within-tree variability in litter characteristics (Section 2.2). Furthermore, for studies conducted at large spatial scales, some sites may exist outside the range of the chosen plant species, with potential consequences for decomposition. However, the home-field advantage hypothesis, which posits that litter decomposition will be most rapid near its source because organisms there are better adapted to use this litter as a substrate and food source than organisms away from the litter source, does not seem to be of concern in streams if high-quality leaves are used $[118,119]$. Lastly, the thermal conditions under which plants grow can influence the litter quality and decomposition rates. For instance, warming can increase the carbon:nitrogen and carbon:phosphorus ratios of the litter, which are attributes that slow decomposition 
rates [120,121]. Consequently, even when the same individual trees are used as a source of litter from year to year, litter quality can vary due to interannual variations in weather. These and other sources of variation in litter quality pose significant problems for developing a standardized, reliable assay based on leaf litter decomposition that can be applied across long-term and large-scale studies.

Decomposition rates can show complex responses to environmental change, complicating the interpretation of results from the perspective of accurate bioassessments. Nutrient loading to freshwaters is widespread across the globe, with nutrient concentrations usually becoming elevated by agriculture and urbanization. Across broad nutrient gradients, there is a hump-shaped relationship between litter decomposition rates and nutrient concentrations ([80]; Section 2.2). This means that identical decomposition rates can be observed at very different levels of nutrient loading, with peak rates being found at moderate levels of ecosystem impairment [80]. This is notable because the streams most in need of bioassessment are those that are moderately impaired by human activities; the ecological condition of pristine streams and of heavily impacted streams is often more obvious. However, given the broad range of nutrient loading required to fully elicit a hump-shaped response, knowledge of the approximate nutrient status of the ecosystem in question is useful in determining which side of the hump it is on, as well as its likely response to changed nutrient concentrations. Furthermore, nutrient enrichment effects may be more easily detected when using low-nutrient rather than high-nutrient litter (e.g., Quercus spp. vs. Alnus spp.) exposed to macroinvertebrates (i.e., in coarse- vs. fine-mesh bags) $[77,80]$.

Water temperature is a critical consideration when using litter decomposition as a means of bioassessment because it influences the community composition and activity of microbes and shredding invertebrates (Section 2.2). Depending on the aims of the bioassessment, the temperature may be a factor of interest or something to be controlled for in order to minimize temperature-caused variation in decomposition rates. The temperature may naturally vary between streams or it may co-vary with other environmental changes, and removing the effects of temperature through the use of temperature-corrected decomposition rates enables a focus on the effects caused by other environmental changes. The most common means of temperature correction is to substitute degree days for time when calculating decomposition rates; this assumes a linear relationship between decomposition rates and temperature $[85,86,122,123]$. Such an approach is easily done given the wide availability and low cost of temperature loggers.

Insect shredders and microbial decomposers potentially respond in contrasting ways to warming (Section 2.2), meaning that overall decomposition rates might not change much in response to warming $[85,87]$. In such instances, quantifying the respective contributions of shredders and microbes, for example, by combining coarse- and fine-mesh litter bags, would be a powerful tool to evaluate warming effects; the ratio of microbial decomposition:invertebrate decomposition should increase along warming gradients $[85,124]$.

Another matter of concern in bioassessment is the high degree of within-stream spatial heterogeneity for variables such as water velocity, substrate size, and water depth, many of which influence decomposition rates ([52,125,126]; Section 2.2). Habitat units in streams often have consistent characteristics; for example, riffles are characterized as being shallow, with turbulent and rapid flow relative to pools that are deeper and have slower water velocities. In order to account for between-habitat variation in environmental conditions and to improve the sensitivity of litter decomposition as a bioassessment tool, substrates should be deployed in a single habitat across streams, that is, either in riffles, runs, or pools that are not too deep. The higher current velocities in riffles relative to other habitats help to ensure that sedimentation is minimized, and the shallow water helps to ensure that researchers can deploy or retrieve experimental materials (e.g., litter bags) during high flow. If physical fragmentation by high currents is a risk, leaves in fine-mesh bags or wood substrates can be used, which are more protected from or resistant to abrasion, respectively. Deep pools, where water velocity is generally low, should be avoided to prevent the accumulation of natural litter and sediments on top of litter bags that can create anoxic conditions. Between-habitat variability is not exclusive to litter 
decomposition studies, as it also affects other bioassessment tools, and practitioners use stratified sampling to reduce this variation.

Classification of streams and rivers into typologies is a requirement for all bioassessment aspects to allow for a comparison of systems with similar geology, climate, hydrological regime, and size features [127]. This classification has the potential to reduce the inherent variability in organic matter decomposition between streams and make it more sensitive for bioassessment. For instance, in a global study, 550 streams were classified by the biome, which explained $30 \%$ of the variation in decomposition rates [86]. However, considerable variation was found between streams even within biomes, which was attributed to differences in geology, temperature, and other factors. In a study of 19 streams distributed throughout three regions that differ in climate and geology in Ontario, Canada, temperature-corrected decomposition rates were explained more by geology than by the other factors examined, including habitat (i.e., pools and riffles) and season [123]. When an effort was made to compare the decomposition rates between watersheds and streams of different sizes and habitats within a geologically homogenous area in the Black Forest of Germany, very little variation in decomposition rates was observed [128], illustrating that when this key factor is accounted for, the background variation between streams and habitats may not be great.

Carbon substrates, such as cotton fabric and small pieces of milled wood (e.g., tongue depressors, coffee stirrers, toothpicks), offer a more standardized and reproducible tool for bioassessment than leaf litter. The use of standardized substrates eliminates the variation that stems from intrinsic substrate characteristics, and therefore, allows for the direct evaluation of the extrinsic drivers of organic matter decomposition, such as nutrient availability. Each of these materials consists largely of cellulose, the most abundant polymer on Earth and the main constituent of plant litter; as such, cellulose is highly relevant for the food webs of most stream ecosystems, and for global biogeochemical cycles. Cotton is approximately $95 \%$ cellulose and wood is about $70 \%$ cellulose. Wood, however, is more chemically complex and has a considerable quantity of lignin (15-40\% across tree species [129]). Several cotton strip types and wood species have been used in recent years. In the case of cotton strips, the types that have been most commonly used (artist's canvas, calico cloth, and Empa fabric (Empa fabric, Dübendorf, Switzerland)) respond very similarly when exposed to identical environmental conditions, and the strong relationships between the cotton strip types suggest that regardless of which one is used, their decomposition rates can be expressed in common units and directly compared (e.g., artist's fabric equivalents [99]). In the case of wood, differences between species are known [130,131], and the decomposition rate increases with the wood surface area:volume ratio [132], but the relationships between the different forms and species of wood used to date (e.g., tongue depressors, coffee stirrers, toothpicks, twigs) remain to be established.

The key advantages of both cotton strips and wood are that they are very simple, inexpensive, and portable, which are attributes that facilitate applications at large spatial and temporal scales. Additionally, as large homogenous batches of the substrate can be acquired and easily stored, cotton- and wood-based assays have a much greater potential for standardization than leaf litter does. Unlike most decomposition assays that rely on the determinations of mass loss for calculating decomposition rates, cotton-strip assays usually rely on the loss of tensile strength, a process that corresponds with the catabolism of cellulose [133]. A drawback of cotton strips is that a tensiometer is required for tensile strength measurements, although such instruments are common at universities and research centers, and there are laboratories that can determine tensile strengths on a contract basis. Additional advantages are that both cotton strips and wood have been found to be sensitive to concentrations of dissolved nutrients $[130,134]$ and other environmental stressors, including heavy metals [135], acidification [99], warming [136], and releases from wastewater treatment plants [110]. The "hump-shape problem" mentioned above for leaf litter may not be an issue for cotton strips and wood because the decomposition of these materials does not involve the feeding activity of invertebrates to the same degree as leaf litter. Lastly, like leaf litter, both cotton strips and wood allow 
for the sampling of microbial communities and functional genes, which are approaches that offer the potential for further insights into ecosystem functioning and bioassessment [137].

A key drawback to using cotton strips and wood is that the decomposition of these two substrates is less likely to involve the activity of invertebrates than leaf litter (this is especially true for cotton strips); this is a less important problem in streams where shredders are naturally rare or absent. Furthermore, although cotton strips and wood are made from natural organic matter, they are deployed in a state that lacks environmental realism (a woven fabric in the case of cotton strips, and a piece of milled wood in the case of commercial wood substrates). Despite this shortcoming, cotton strips have been found to have a similar number of microbial taxa colonizing it as leaf litter [99], including both bacteria and fungi [110,137], and cotton strip and wood decomposition track leaf litter decomposition when placed in similar environmental conditions [29,138].

Incubation times between cotton strip and wood assays vary substantially. In the case of cotton strip assays, the incubation period in streams ranges from about 3-6 weeks in duration in order to achieve a $50 \%$ tensile strength loss, which is the degree of decomposition at which the assay is believed to be most sensitive to environmental conditions. Wood requires at least several months before an appropriate level of mass loss is achieved, although the thickness of the wood can be manipulated in order to control the surface area:volume ratio and the incubation period [132]. Because wood and cotton strip assays vary in their incubation durations, their decomposition rates integrate environmental conditions over different timescales, which is an attribute of the assays that could be exploited to meet research or bioassessment goals.

To help to evaluate and compare the usefulness of three of the most common methods for evaluating organic matter decomposition, we compiled a table of 12 attributes for leaf litter, wood, and cotton strips (an approach modified from [14]) as they relate to bioassessment (Table 1). The performance was similar for cotton strips and wood, with the key strengths being the ease of use, large-scale applicability, and repeatability, while the drawback is the limited involvement of invertebrate feeding. The key strengths of leaf litter are that it is an environmentally realistic substrate and incorporates the activity of invertebrates.

Table 1. Attributes for leaf litter, wood, and cotton strips as they relate to bioassessment. The performances of each substrate, based on our opinion, rank from weak (light grey) to moderate (dark grey) to strong (black).

\begin{tabular}{l|lll}
\hline Attributes & Leaf Litter & Wood & Cotton Strips \\
\hline Derived from sound theoretical concepts in ecology & & & \\
A priori predictive & & & \\
Sensitivity to common stressors & & \\
Potential to discriminate anthropogenic disturbances & & \\
Linear stressor-decomposition relationship & & \\
Large-scale applicability & & \\
Incorporates the feeding activity of invertebrates & & \\
Realism of substrate & & \\
Ease of use & & \\
Cost of use & & \\
Incubation duration & & \\
Repeatability & & \\
\hline
\end{tabular}

\section{Ecosystem Metabolism}

\subsection{Major Moderators and Sensitivity to Environmental Change}

Metabolism is defined as "the chemical processes that occur within a living organism in order to maintain life" [139]. Because the metabolism of any organism includes a myriad of entangled chemical reactions, researchers often summarize it by means of a common currency, such as oxygen consumption. This trend is even more marked when researchers attempt to characterize the metabolism 
of communities or whole ecosystems. Here, we follow this trend, even if we acknowledge that in many ecosystems, a significant fraction of the metabolism is anaerobic and, thus, does not leave a direct imprint on oxygen concentrations [140-142].

In streams and rivers, changes in the DO concentrations are driven by a physical exchange between the water column and the atmosphere (i.e., reaeration) and two key biological processes, namely, photosynthesis and respiration. River researchers usually refer to these processes as gross primary production (GPP) and ecosystem respiration (ER), with net ecosystem productivity (NEP) being the difference between both processes.

The main drivers of GPP and ER are well known (see the review by [143]). Gross primary production is primarily controlled by light, temperature, and nutrients, followed by a host of other factors ranging from the stability of the substrate to the biomass and type of primary producers. Ecosystem respiration is mainly driven by the supply of easily degradable organic matter and oxygen, temperature, and the biomass of heterotrophs, predominantly of microbial decomposers. These drivers change across river types and seasons [144], resulting in river-specific metabolic regimes [145,146].

River GPP tends to change longitudinally with the size of the river, as the drivers of photosynthesis show strong gradients from headwaters to river mouths. As underlined by the classic River Continuum Concept (RCC) [147], GPP is typically light-limited in headwater forest streams, tends to increase in large streams to medium-sized rivers as the canopy opens [148], and decreases again in large rivers, where the turbidity and depth limit photosynthesis [149]. Nevertheless, many river systems are far from the conceptual pattern depicted in the RCC. For instance, geomorphologies often show abrupt longitudinal changes (e.g., from a dark, narrow canyon to a wide, braided reach), and so does ecosystem functioning [150]. Rivers draining natural grassland areas can have a high GPP in unshaded headwaters [151,152]. Similarly, the slow and nutrient-rich Pampean streams can be extremely productive [153], whereas highly turbid rivers tend to be unproductive [154,155]. Furthermore, human activities, such as the clearing of riparian forests or the building of reservoirs, cause many rivers to depart from the predictions of the RCC [156].

GPP also shows a strong seasonality in most streams and rivers, peaking during periods of high light availability and low, stable flows [157]. Conversely, GPP can be severely reduced by floods, which scour away primary producers [158-160], as well as when the river dries out [161]. Herbivores, such as snails and some fish, can also severely reduce algal biomass during long periods of stable flow, although the effect on GPP generally seems weak [162]. Moreover, flow stability below large reservoirs promotes an increase in algal biomass and metabolism [163], although very long periods of hydrological stability can promote algal senescence and thus reduce GPP [159]. Regarding light, GPP has traditionally been found to increase with light availability, but becomes saturated at high irradiances, although this relationship has been formalized for phytoplankton [164] and less so for other riverine producers. Nevertheless, the multiple requirements for high GPP (e.g., abundant light and nutrients, low and stable flows, low presence of herbivores) often result in narrow "windows of opportunity" for primary producers [165], which also contrast across ecoregions [166]. Therefore, multiple measurements of GPP (over several days or weeks) would allow for the integration of temporal variations into the stream metabolism [146].

Regarding ER, temperature and the availability of organic matter have been described as its main drivers $[143,167,168]$. However, it has been experimentally shown that nutrients also promote stream ER [169]. There is a great degree of coupling between GPP and ER, as a significant part of the organic matter synthesized during photosynthesis is immediately respired by autotrophs and their closely associated heterotrophs [170]. However, catabolic processes are more sensitive to changes in temperature than anabolic processes, and thus, warming should have stronger effects on ER than GPP [168]. In addition, stream respiration increases with temperature, irrespective of the background temperature [171]. Together, these observations have led to predictions that global warming will reduce stream NEP [168,172]. In line with this, the seasonality of ER seems mainly driven by changes in temperature and the inputs/storage of terrestrial organic matter [161], although in human-modified 
streams, other factors, such as inputs of sewage water with high biological oxygen demand, can also exert an influence [173]. Other factors that affect water temperatures, such as riparian deforestation, flow reduction, and flow regulation by dams, will also affect ER.

Because GPP and ER are affected by so many factors, river metabolism is sensitive to most environmental pressures [12]. In particular, whole-ecosystem metabolism has been shown to respond to pollution [159,174], eutrophication [173-175], altered light regimes [176,177], channelization [178,179], flow regulation [163,180,181], altered sediment dynamics [13], drought [182], altered thermal regimes [167], salinization [183], acidification [184], and altered organic matter resources [185].

Of particular concern can be land uses, such as agriculture or intensive forestry (especially in the case of short-term rotation plantations), contributing large amounts of fine particles to river channels, as these reduce the light reaching the bottom, clog the river bed, and impact riverine communities [186,187], but can also be a source of nutrients and promote biofilm growth [188]. Changes in riparian cover, such as those derived from riparian deforestation, are also important because they directly affect the light and temperature regimes [189,190]. Additionally, invasive species, such as the diatom Didymosphenia geminata or some Microcoleus cyanobacteria, can have an important effect on benthic communities [191], and probably on ecosystem metabolism [192]. Moreover, there is a growing concern regarding the effects of emerging pollutants, as many of these novel substances are very biologically active [193]. These pollutants are most often found in complex cocktails, and together with other classic pollutants, making their environmental effects difficult to discern [194]. In general, rivers are subject to multiple stressors, which makes it difficult to prioritize and understand the effects of individual stressors [195]. Urban streams and rivers are probably the ones experiencing the most complex multi-stress effects, as depicted in the urban stream syndrome, which collectively has strong effects on their metabolism [196].

\subsection{Practicability of Ecosystem Metabolism as a Bioassessment Tool: Methods, Strengths, and Limitations}

In streams and rivers, ecosystem metabolism can be measured in a variety of ways using either (I) compartment-specific approaches that enclose a part of the ecosystem (e.g., plankton bottles, benthic chambers), which estimate "community metabolism," or (II) open-channel approaches, which estimate whole ecosystem metabolism from spatial or temporal changes in oxygen concentration in a water body $[197,198]$. In some studies, compounds other than oxygen (e.g., $\mathrm{CO}_{2}$, resazurin-resorufin) have been used to estimate stream ecosystem metabolisms. However, these studies are scarce, especially in bioassessment (see Section 4), and thus, here we focus on oxygen. Metabolism involves both the production and uptake of DO, and thus, most metabolism measurement methods are based on oxygen changes and rates of metabolism are typically reported using units of oxygen production or uptake over time [199]. Coincidentally, the raw measurements of DO, and particularly the daily DO minima, are also extremely useful information from an ecosystem integrity perspective since it indicates whether minimum DO concentrations may stress aquatic life. In such instances, metabolism measurements can be used to help diagnose the cause of the low daily DO minima [200].

One of the challenges in measuring metabolism is the estimation of the amount of oxygen exchanged with the atmosphere, which is controlled by the departure from the oxygen saturation equilibrium and the reaeration coefficient. A range of methods can be used to estimate the reaeration coefficient, including gas tracer measurements, empirical equations relating hydraulic properties with reaeration, and methods/models using the oxygen record itself [201,202]. A range of spreadsheets and models are available to calculate metabolism estimates on either a daily or multi-day basis (e.g., [203-205]). These approaches generally work well but careful calibration and maintenance of DO loggers are essential, along with robust quality assurance/quality control systems for the collected data. Particular caution needs to be taken when there are weak diurnal DO signals and/or with data collected under conditions where the assumptions of the various mathematical models might be broken, such as where there are substantial groundwater inputs, or where significant rainfall alters processes controlling the exchange of oxygen with the atmosphere [202]. 
Ecosystem metabolism responds to a wide variety of drivers and these responses are quite well known and predictable (Section 3.1), making ecosystem metabolism a strong candidate as an indicator of ecosystem functional integrity in bioassessments of the effects of different stressors [13,143]. The broad range of drivers influencing metabolism also makes it a potentially useful indicator for determining the effectiveness of catchment rehabilitation efforts $[176,206,207]$. Nevertheless, the same broad range of factors may also be a challenge for bioassessment programs because the baseline expectations of metabolism will vary depending on the natural flow regime, the vegetation and shading from riparian margins, and the load of nutrients and organic matter. Young et al. [13] provided some initial guidelines for interpreting ecosystem metabolism measurements using either a comparison with a reference approach or an absolute values approach. Identifying an appropriate reference condition can be challenging for many river types, while the range of what are considered "normal" rates of GPP and ER is expected to broaden as metabolism information becomes available from a wider range of sites and conditions and over longer periods $[144,145,165]$.

Whole-ecosystem metabolism considers ecosystem functional integrity at spatial scales from the reach through to the whole river network, and from hours through to months/years on a temporal scale [12]. This integrative characteristic can be very important in assessments of ecosystem functional integrity for larger rivers where the deployment of a DO logger close to the thalweg is easy, whereas the appropriate spatially replicated sampling of structural indicators, such as invertebrates across multiple habitats, is difficult or impossible due to high depths and/or current velocities [208]. The ability to assess conditions over a long period, while potentially using historical DO records, is also a strength of whole ecosystem metabolism studies [173]. Continuous DO records enable temporal variability in metabolism to be determined [146], with the level of temporal variability itself being a useful indicator of the resilience of ecosystems [209]. If a more specific focus is required, then compartment-specific assessments can help to determine the role of different ecosystem compartments in the overall ecosystem metabolism [210].

Cost and complexity are important elements to consider in bioassessment program design and have often been considered a barrier to the inclusion of functional indicators in bioassessment programs [12]. Whole ecosystem metabolism can be easily measured using a single-station approach, which is also amenable to the automated use of historic or real-time continuous DO data. Compartment-specific metabolism measurements are more demanding in terms of equipment and resources but may be suitable for ecosystem integrity assessments if a single compartment of the ecosystem is of particular interest and/or resourcing is sufficient [211]. DO loggers are required for any metabolism measurements, but the cost of high-quality equipment is continuing to decrease, making the deployment of continuous DO sensors more affordable [146].

\section{Systematic Map: Organic Matter Decomposition and Ecosystem Metabolism as Bioassessment Tools of Stream Functional Integrity}

Over the last two decades, a large number of studies have addressed organic matter decomposition and ecosystem metabolism as bioassessment tools of stream functional integrity. Here, we review this literature using a systematic approach to describe the evidence base and produce a systematic map (i.e., a visual synthesis of the data focusing on methodological aspects of the studies) [212].

Literature searches to locate all studies that have addressed the use of organic matter decomposition or ecosystem metabolism as bioassessment tools of stream functional integrity were carried out using Web of Science (WoS; Core Collection, Science Citation Index Expanded) on 12 and 13 May 2020, and focused on the period 2000-2020. We used the following search strings (applied to all fields): ((decomposition OR breakdown) AND (stream OR river) AND (integrity OR assessment OR health OR status)) to locate the literature addressing organic matter decomposition, and ((metabolism OR primary product* OR respiration OR photosynthesis) AND (stream OR river) AND (integrity OR assessment OR health OR status)) to locate the literature addressing ecosystem metabolism. 
A total of 1202 studies were detected in the organic matter decomposition search. After screening the titles and abstracts, and checking the eligibility (performed by a single reviewer), 80 studies (papers) were retained as they explicitly addressed the use of organic matter decomposition as a bioassessment tool (Figure S1). The list of retained studies was reviewed by the authors and was complemented with an additional eight papers that were considered relevant but that were not detected in the initial WoS search (Figure S1). A total of 88 studies were thus included.

For the ecosystem metabolism search, a total of 3033 studies were detected. The studies were split between three reviewers for the screening of titles and abstracts and the eligibility checking. The list of eligible studies was discussed between the reviewers until consensus was reached. Forty-eight studies (papers) were retained as they explicitly addressed the use of ecosystem metabolism as a bioassessment tool (Figure S2). The list of retained studies was complemented with another two papers that were considered relevant but that were not detected in the initial WoS search (Figure S2). A total of 50 studies were thus included.

All studies that were included had their full text screened and the following data were extracted: (I) bibliographic information (e.g., source, full reference, study approach), (II) identification of the environmental change addressed, (III) experimental choices (e.g., location, lotic system, methodological approach), and (IV) interpretation of the author about the usefulness of litter decomposition and ecosystem metabolism as a bioassessment tool. For review papers, only the information on (I) and (IV) was extracted (Tables S1 and S2).

Leaf litter decomposition was used as a bioassessment tool of stream functional integrity as early as 1994 [213]. Over the period that we focused on (2000-2020), the first paper addressing organic matter decomposition as a bioassessment tool dates from 2001 [214] and was followed by a seminal conceptual paper on the topic [1]. The number of papers addressing organic matter decomposition as a bioassessment tool increased at a rate of 1.4 papers/year between 2001 and 2005, and by 5.6 papers/year between 2006 and 2020 (Figure 1). The first paper addressing ecosystem metabolism as a bioassessment tool over the period from 2000 to 2020 dates back to 2005 [215]. Young et al. [13] was the first review paper focusing on the usefulness of ecosystem metabolism as an indicator for assessing river functional integrity. The number of papers on ecosystem metabolism as a bioassessment tool has increased at a rate of 3.5 papers/year between 2005 and 2020 (Figure 1).

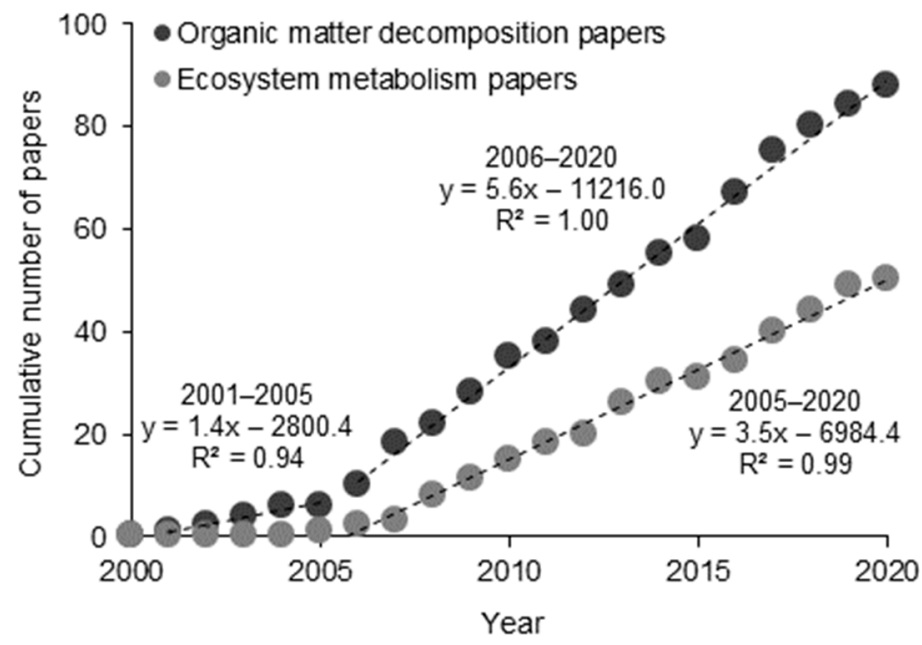

Figure 1. Cumulative number of papers addressing the use of organic matter decomposition $(n=88)$ or ecosystem metabolism $(n=50)$ as bioassessment tools of stream functional integrity over the last two decades. Linear regressions are shown for the periods 2001 (first study)-2005 and 2006-2020 for organic matter decomposition papers and for the period 2005 (first study)-2020 for ecosystem metabolism papers. 
Papers addressing organic matter decomposition as a bioassessment tool have been published in 30 scientific journals (Table S3), but nine journals alone published $75 \%$ of all papers, with Freshwater Biology (18 papers), Ecological Indicators (13), and Freshwater Science (formerly Journal of the North American Benthological Society; 10) being the most frequently selected journals (Figure 2a). The remaining 21 journals published 1-2 papers each, contributing 25\% of the published papers. Among the most frequently selected journals, three have a marked applied character (Ecological Indicators, Ecological Applications, and Water Research). Ecological Indicators and Water Research, in particular, have been selected mostly in recent years ( $\geq 2013$ and $\geq 2017$, respectively). In fact, the number of papers published in journals with an applied character since 2013 represented $52 \%$ of the total number of papers published in that period (44), while they represented only $9 \%$ of the total number of papers published in 2001-2012 (44) (Table S3). This increase in the number of papers published in more applied journals in recent years suggests that researchers were undertaking efforts to disseminate the use of organic matter decomposition as a bioassessment tool among stakeholders and decision-makers.

(a)

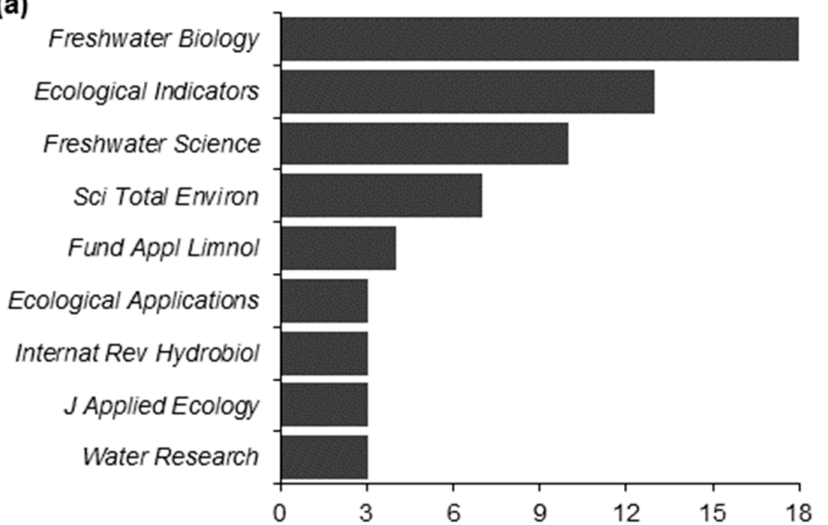

(b)

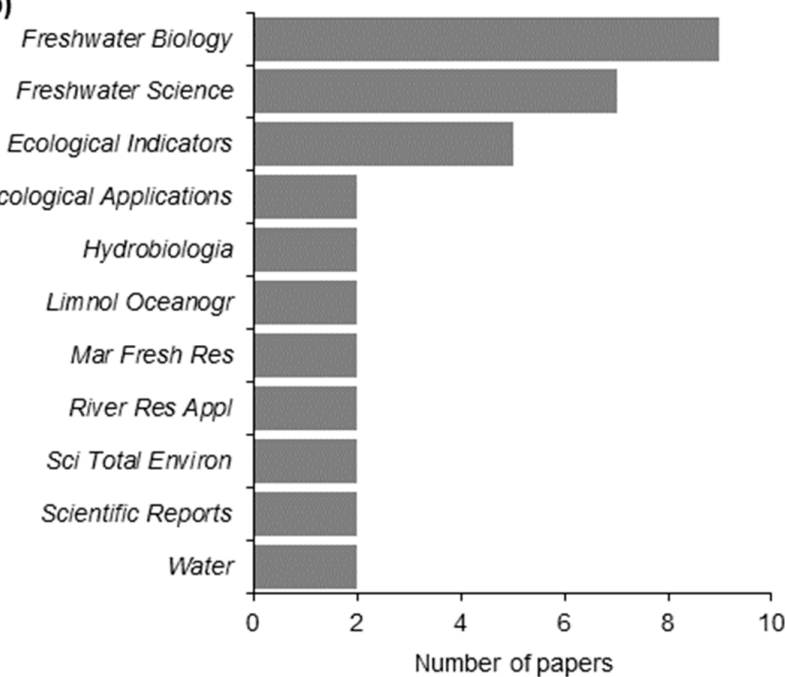

Figure 2. (a) Scientific journals that published $\geq 3$ papers ( $75 \%$ of the total number of papers) addressing the use of organic matter decomposition as a bioassessment tool of stream functional integrity; 21 other journals published 1-2 papers each (see Table S3). (b) Scientific journals that published $\geq 2$ papers (74\% of the total number of papers) addressing the use of ecosystem metabolism as a bioassessment tool to measure stream functional integrity; 13 other journals published 1 paper each (see Table S4). Abbreviations of journal names are as follow: Sci Total Environ-Science of the Total Environment, Fund Appl Limnol_Fundamental and Applied Limnology, Internat Rev Hydrobiol_International Review of Hydrobiology, J Applied Ecology_Journal of Applied Ecology, Limnol Oceanogr-Limnology and Oceanography, Mar Fresh Res-Marine and Freshwater Research, River Res Appl-River Research and Applications. 
Papers addressing ecosystem metabolism as a bioassessment tool have been published in 24 scientific journals (Table S4). Again, Freshwater Biology (9 papers), Freshwater Science (7), and Ecological Indicators (5) were the most frequently selected journals (Figure 2b). Eleven journals published $\geq 2$ papers, representing $74 \%$ of the total number of papers, while the remaining 13 journals published one paper each, contributing to $26 \%$ of the published papers (Figure 2b). Papers published in journals with an applied character represent only $32 \%$ of the total number of papers, but this proportion has been increasing in recent years (Table S4).

The studies varied in their approach (Tables S1 and S2), with several combining different approaches (Table S3). Stream bioassessment using organic matter decomposition was addressed in 75 papers, while 11 papers addressed methodological aspects and 11 reported reviews (Figure 3a). Overall, there were 81 field studies (i.e., reported assessment and/or methodological aspects based on field incubations of litter). Stream bioassessment using ecosystem metabolism was addressed in 43 papers, while five were reviews, one addressed methodological aspects, and one had a modeling approach (Figure 3b). Overall, there were 44 field studies (i.e., excluding the five reviews and the modeling study).

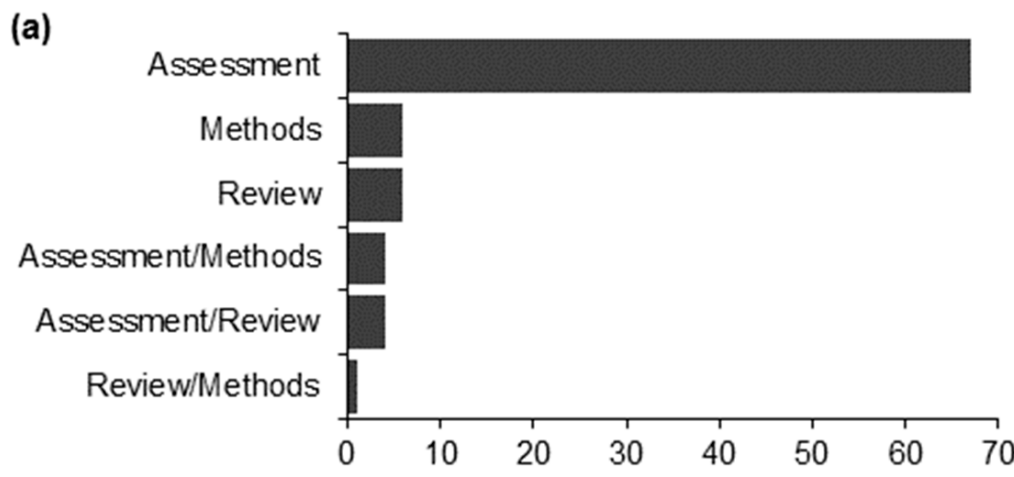

(b)

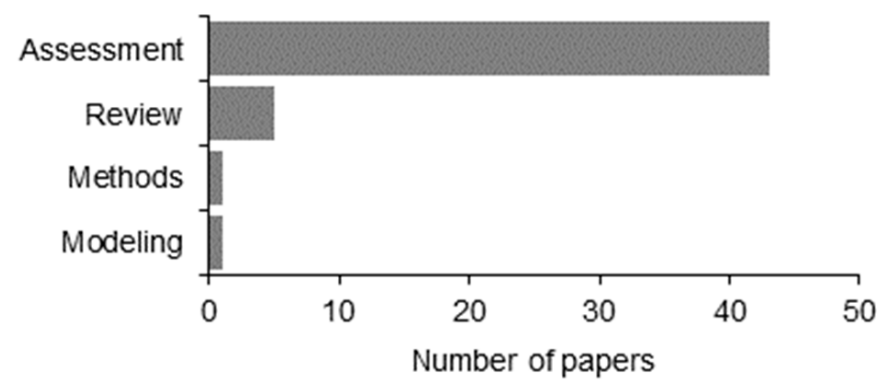

Figure 3. Approaches used in the papers addressing the use of (a) organic matter decomposition $(n=88)$ or $(\mathbf{b})$ ecosystem metabolism $(n=50)$ as bioassessment tools of stream functional integrity (for the definitions, see Tables S1 and S2).

Bioassessment studies have addressed the usefulness of organic matter decomposition (75) or ecosystem metabolism (43) as functional indicators under a large variety of environmental changes, which were grouped into 12 and 11 types, respectively (Tables S3 and S4). Environmental changes most represented in bioassessment studies using organic matter decomposition were driven by agriculture/pasture (16 studies), forestry (14), industry/urbanization (11), and nutrient enrichment/eutrophication (11) (Figure 4a). Interestingly, three studies used organic matter decomposition to assess the effects of restoration practices on stream functioning ([207,216,217]; Figure 4a). Environmental changes that were most represented in bioassessment studies using ecosystem metabolism were driven by agriculture/pasture (22 studies), industry/urbanization (12), organic pollution (7), hydromorphologic pressures (3), forestry (3), restoration (3), and mining (2) (Figure 4b). Other environmental stressors (i.e., nutrient enrichment, warming, heavy metals, and other land-use changes) were only addressed by one paper each (Table S4). 


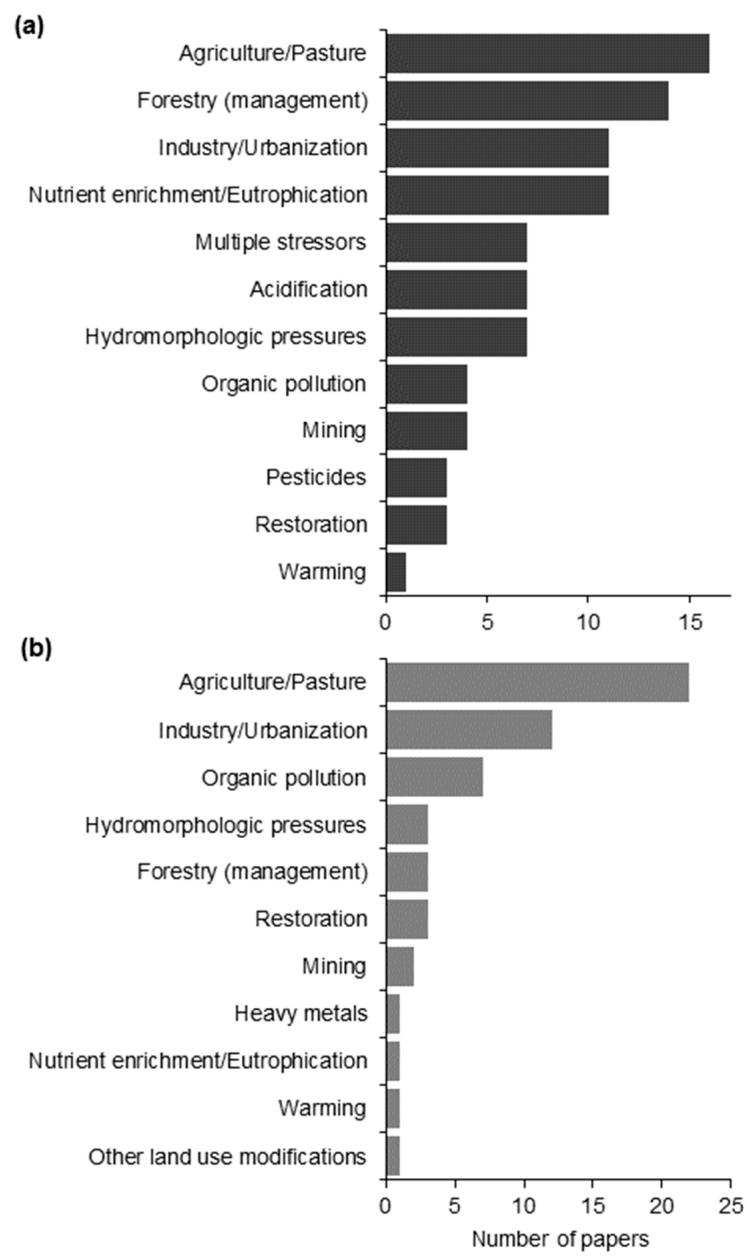

Figure 4. Types of environmental change addressed in bioassessment studies using (a) organic matter decomposition $(n=75)$ or $(\mathbf{b})$ ecosystem metabolism $(n=43)$. Several studies addressed multiple environmental changes and so the sum of the studies across types surpasses the number of bioassessment studies.

Among the field studies addressing organic matter decomposition (81), most were carried out in Europe (39), followed by Oceania (17) and North America (16) (Figure 5a). Studies in South America, Asia, and Africa were less common (10 in total; Figure 5a) and have all been published in the last decade ( $\geq 2011$; Table S3). When considering countries, however, New Zealand was represented in 15 studies, followed by France (11), and the USA and Portugal (10 each) (Figure 5b). The leading role of New Zealand probably reflects an active research community with an interest in this field that is well-linked with local and central government policy and monitoring needs, which is perhaps easier in a small, isolated country with a strong environmental ethic. Among field studies addressing ecosystem metabolism (44), most were carried out in North America (17), followed by Oceania (11), and Europe (10) (Figure 5a). Studies in South America, Asia, and Africa were less common (6 in total; Figure 5a) and were mostly published recently (Table S4). When considering countries, the USA was represented in 15 studies, followed by New Zealand (7), Spain (5), Australia (4), and Brazil and Canada (3 each) (Figure 5c). The leading role of the USA probably derives from the leading role of a few research groups that have been measuring various ecosystem functions over many years. Most field studies using organic matter decomposition (67 (83\%)) and ecosystem metabolism (37 (84\%)) were undertaken in temperate regions, with studies in tropical and boreal regions being less common (Figure 5d). Since important drivers of organic matter decomposition and ecosystem metabolism vary with latitude and across regions (e.g., temperature [85,86,172], light [144,218], diversity of aquatic hyphomycetes [219], diversity and abundance of shredders [220]), it would be important to more 
widely examine the use of organic matter decomposition and ecosystem metabolism as bioassessment tools in tropical and boreal regions.

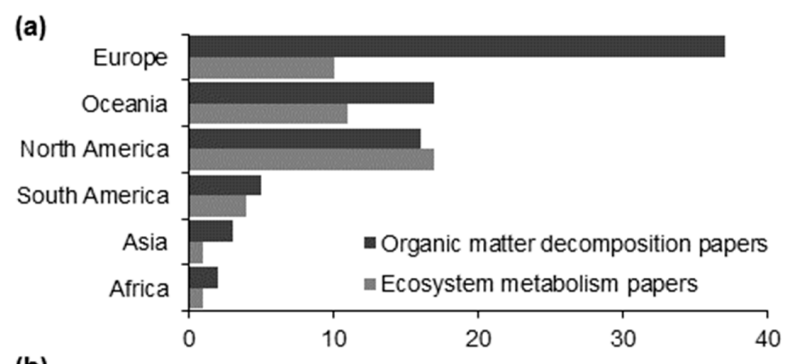

(b)
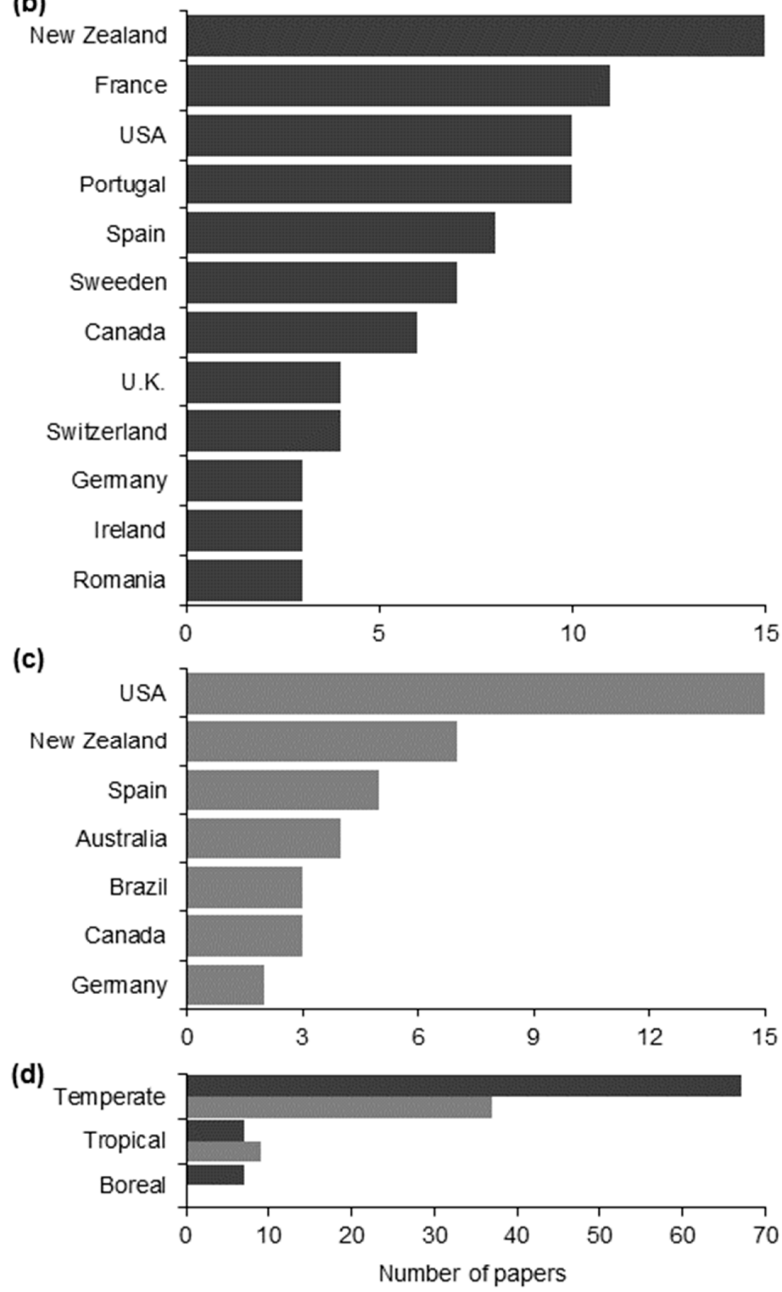

Figure 5. (a) Distribution of field studies addressing organic matter decomposition $(n=81$; review and review/methods studies were not considered) or ecosystem metabolism $(n=44$; review and modeling studies were not considered) as bioassessment tools by continent. (b) Representation of countries in field studies using organic matter decomposition as a bioassessment tool; only countries represented in $\geq 3$ studies are shown (a further 11 countries were represented in 1-2 studies; Table S3). Several studies were carried out in multiple countries (2-9 countries/study) and so the sum of the studies across countries surpasses the number of field studies. (c) Representation of countries in field studies using ecosystem metabolism as a bioassessment tool; only countries represented in $\geq 2$ studies are shown (a further seven countries were represented in one study each; Table S4). (d) Distribution of field studies addressing organic matter decomposition or ecosystem metabolism as bioassessment tools by regions (for the definitions, see Tables S1 and S2). 
Field studies addressing organic matter decomposition (81) were carried out in three types of lotic systems: rivers, streams, and artificial streams (i.e., farm ditches, constructed channels, constructed streams; Table S1), with some studies being carried out in multiple lotic systems (Table S3). Streams were considered in 67 studies, rivers in 13, and artificial streams in four (Figure 6a). The dominance of streams in field studies was not surprising since organic matter decomposition is a fundamental ecosystem function especially in small watercourses where the riparian vegetation provides shade and allochthonous organic matter [221,222]. However, organic matter decomposition can also be an important function in the littoral areas of large rivers $[26,223,224]$, which justifies its use as a functional tool in these environments. However, organic matter decomposition was not effective as a bioassessment tool, or its efficiency was not clear, in a larger percentage of studies in rivers (33\%) than in streams (21\%) (Table S3), suggesting that decomposition may be more efficient at detecting environmental change in small rather than large watercourses.

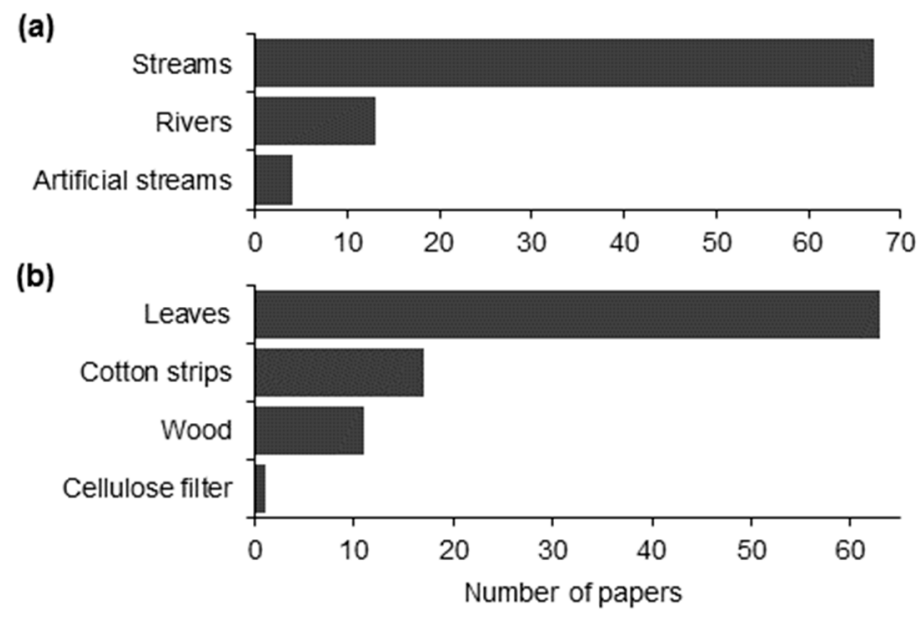

Figure 6. Representation of the (a) lotic systems and (b) substrate types in field studies addressing organic matter decomposition as a bioassessment tool $(n=81)$. Several studies were carried out in multiple types of lotic systems and used multiple types of substrates, and so the sum of the studies across systems or substrates surpasses the number of field studies.

Field studies assessed decomposition on four types of organic substrates, with nine studies using at least two types (Table S3). Leaves were the substrate most often used (63 studies), followed by cotton strips (17) and wood (including commercial wood substrates; 11); cellulose filters were used in one study (Figure 6b). Leaves generally dominate the annual plant litter input to streams [225], and their use in bioassessment studies is thus ecologically sound. Wood may also be important in litter inputs to streams [225] and generally makes a large contribution to the benthic organic matter storage owing to its slow decomposition $[131,225,226]$, which also justifies the use of wood substrates in bioassessment studies. Cotton strips are a commercial, highly standardized substrate, which has been used to assess cellulose decomposition potential in soils since the 1970s [227]. In 2000, Boulton and Quinn [228] used cotton strips for the first time in streams, and in 2009, Young and Collier [65] used them to assess stream functional integrity. Their use has become more common after the publication of a cotton strip protocol in 2013 [133] (Table S3). Interestingly, cotton strips (11 studies) and wood (5) were more common substrates in studies in New Zealand than in other countries, and within New Zealand, more common than leaves (5 studies) (Table S3). Artificial substrates as commercial wood or cotton strips show standardized physical and chemical characteristics, which reduce the within-stream variability in decomposition rates and increase the potential to detect differences between streams that result from human activities (Section 2.3). In contrast, leaf litter shows intraspecific and inter- and intra-individual variability in physical and chemical characteristics (Section 2.2), which may result in larger within-stream variability of decomposition rates. The use of standardized substrates that can 
be purchased and deployed without protective enclosures is also less expensive and time consuming compared with the use of leaves that need to be collected and enclosed in mesh bags ([29]; Section 2.3).

Leaf litter was generally incubated in coarse-mesh bags ( 59 studies), followed by fine-mesh bags (36); leaf litter was fastened into leaf packs in 4 studies (Figure 7a). The frequent use of coarse-mesh bags indicates the interest in addressing the overall leaf litter decomposition, i.e. litter decomposition mediated by the activities of both microbial decomposers and invertebrates such that it better mimics what happens to litter when it is naturally submersed. In fact, fine-mesh bags were used only simultaneously with coarse-mesh bags or packs (Table S3), suggesting an interest in comparing the response of microbially driven and overall litter decomposition to environmental change. This comparison is relevant since litter in fine- and coarse-mesh bags/packs may be exposed to different levels of physical abrasion. Fine-mesh bags may confer protection against abrasion by currents and sediments and may be preferred in situations where natural differences in these variables may obscure the effects of environmental changes of anthropogenic origin. Furthermore, microbial decomposers and macroinvertebrates may respond differently to environmental change, or the response by microbes may be exacerbated by invertebrates, with consequent changes in the relative contribution of microbes and invertebrates to leaf litter decomposition [7,77,111,229]. A large number of leaf species (37) was used across the studies, with 15 studies using multiple species (Table S3). Nine species were used in at least two studies, with Alnus glutinosa (25 studies), Quercus robur (10), and Fagus sylvatica (5) being the leaf species that were most often used (Figure $7 \mathrm{~b}$ ). Twenty-eight other species were used only once (Table S3). Interestingly, the three species most often used (A. glutinosa, Q. robur, and F. sylvatica) were exclusive to studies in Europe, indicating a high consistency in species identity despite the studies being carried out across 12 countries (Table S3). Studies in the other 11 countries were spread over five continents (Figure $5 b$ ) and used local species, which explains the high number of species that were used only once.

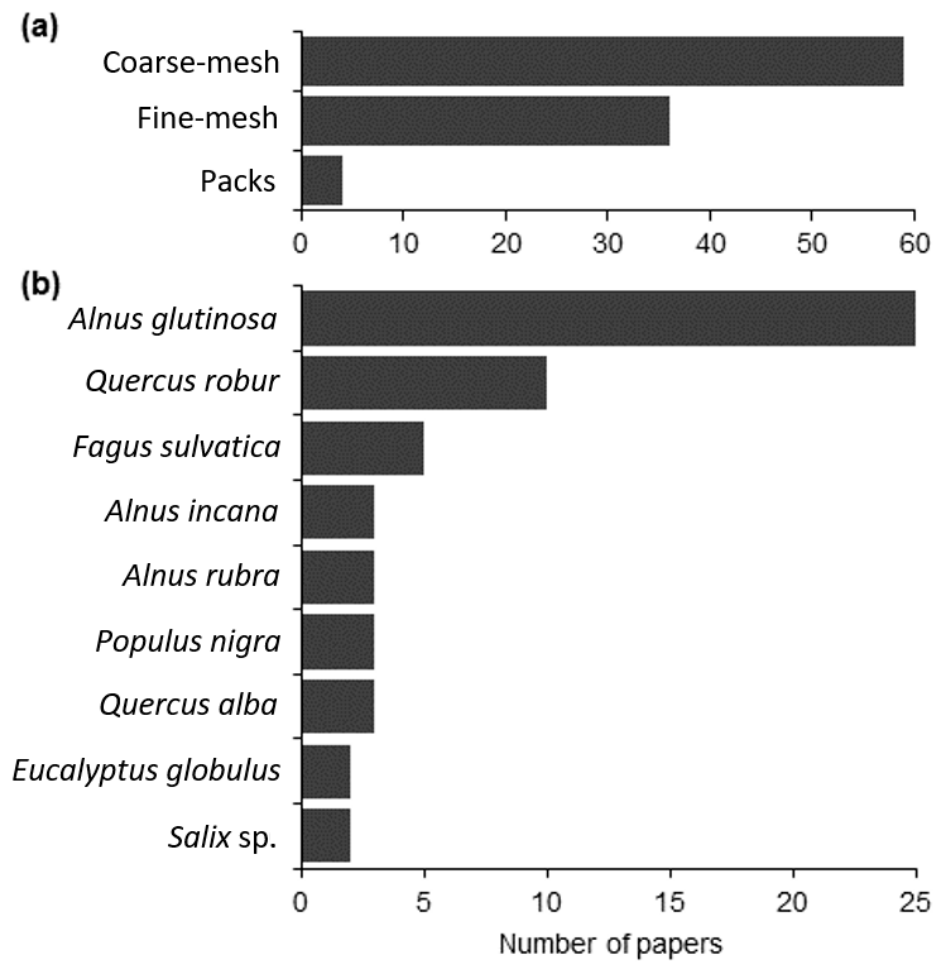

Figure 7. Representation of the (a) mesh size (see definitions in Table S1) and (b) leaf species in field studies that used leaf litter $(n=63$ ); only the leaf species used in $\geq 2$ studies are shown (a further 28 species were used in 1 study each; Table S3). Several studies used both fine-mesh bags and coarse-mesh bags or packs, and multiple leaf species, and so the sum of the studies across mesh sizes or species surpasses the number of field studies using leaf litter. 
Wood substrates were always incubated without an enclosure. Of the six wood types used, commercial substrates dominated, with coffee stirrers being the most common (five studies) (Figure 8a). Six wood species were used, with Betula platyphylla being the most common (four studies) (Figure 8b). Almost half of the studies using wood were carried out in New Zealand (5 out of 11), which explains why B. platyphylla was the most used wood species. Nothofagus rubrus and Betula sp. were also used in studies in New Zealand, while the other three species were used in studies in Europe and the USA (Table S3).

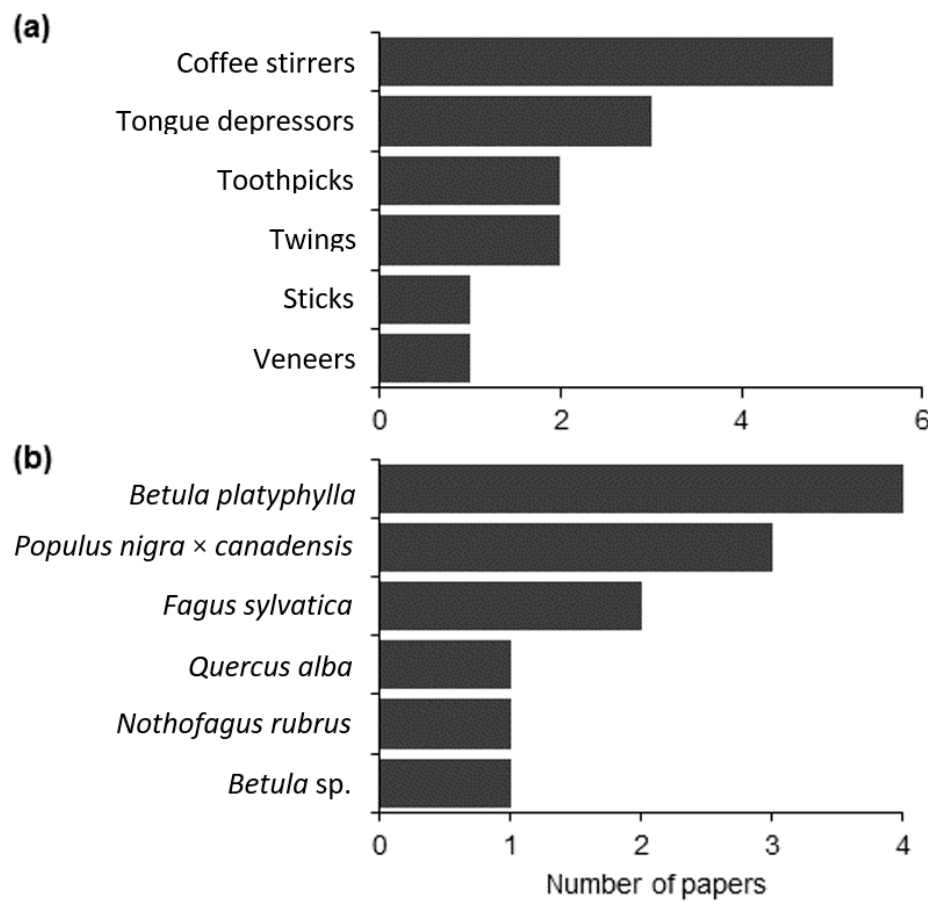

Figure 8. Representation of the (a) wood types and (b) wood species used in the field studies that used wood $(n=11)$. Several studies used multiple wood types or species, and so the sum of the studies across wood types or species surpasses the number of field studies.

Organic matter incubation differed in terms of the season and duration across studies (Table 2). Most studies initiated organic matter incubation in autumn or winter (60 studies) and 10 studies had at least two incubation periods during the year (generally one in the cold season and then again in the warm season) (Table 2). In 39 studies, the litter incubation crossed over at least two seasons (Table 2). The preference for starting studies in autumn or winter is related to the fact that autumnal litter fall contributes a large input of organic matter to streams in temperate regions, and thus the litter decomposition is especially relevant in temperate streams from autumn to spring $[225,230]$.

Field studies addressing ecosystem metabolism (44) were carried out in two types of lotic systems: streams and rivers (Table S2). Streams alone were considered in 30 papers, rivers alone in seven papers, and both systems in seven papers (Figure 9a). These results indicate the bias toward small lotic systems in ecosystem functioning studies and the fact that large lotic systems remain understudied. Field studies used five types of general approaches to determine the ecosystem metabolism (Table S2), with 42 papers showing a spatial comparison approach between two or more sites and only two showing a purely time-series approach within one site (Figure 9b). Of the studies using the spatial comparison approach, 23 used a single measurement per site, 10 used several measurements per site, six used a time series at each site, and three used experimental manipulation. The difference between the approaches seems to reflect practical constraints more than anything else. Although most authors would agree that single measurements can be misleading, as weather (e.g., cloudiness) can exert a large influence on metabolism, deploying multiple probes for longer periods can be impractical for many researchers. Most field studies (34) used the open-channel method, whereas only 10 studies 
used the chambers method (Table S4, Figure 9c). The preference for open-channel methods is probably based on the fact that they are both more integrative and less time-consuming than chamber methods.

Table 2. Season during which organic matter was incubated in field studies $(n=81)$. The slash ("/") indicates that the litter was incubated over multiple seasons; the comma (",") indicates multiple incubation periods.

\begin{tabular}{|c|c|}
\hline Season & No. of Studies \\
\hline Autumn & 13 \\
\hline Autumn/winter & 20 \\
\hline Autumn/winter/spring & 3 \\
\hline Autumn/winter/spring/summer & 2 \\
\hline Autumn, spring & 1 \\
\hline Autumn, summer & 2 \\
\hline Autumn/winter, spring & 2 \\
\hline Winter & 9 \\
\hline Winter/spring & 3 \\
\hline Winter/spring/summer & 1 \\
\hline Winter, summer & 1 \\
\hline Spring & 2 \\
\hline Spring/summer & 1 \\
\hline Spring/summer/autumn & 1 \\
\hline Summer & 8 \\
\hline Summer/autumn & 5 \\
\hline Four seasons & 2 \\
\hline Monthly for 16 months & 1 \\
\hline Dry season & 1 \\
\hline Dry season, wet season & 1 \\
\hline Wet season/dry season & 1 \\
\hline Not reported & 1 \\
\hline
\end{tabular}

Most studies using the open-channel method were based on the single-station procedure (26), whereas fewer studies used the two-station procedure (4) or a combination of both (4) (Figure 10a, Table S4). The single-station procedure seems to be preferred because it is less demanding, with the two-station approach being mostly used when the upstream reach was not homogeneous, and thus, breaching the assumptions of the single-station procedure. All open-channel studies measured the DO. The computation of the metabolic rates was mostly done directly from the DO concentrations via a book-keeping technique (also known as the "accounting" method [197]) (28 studies) and only six studies used a modeling technique to fit high-frequency daily DO curves (Figure 10b, Table S4). However, the use of the modeling technique has become more common in recent years. Reaeration was primarily calculated using the night-time regression technique (16 studies), followed by direct measurement (9), the delta method (5), modeling (4), empirical equations (4), and other techniques (2) (Figure 10c, Table S4). The preference of the night-time regression technique probably reflects its conceptual simplicity, as well as the mixed performance of empirical equations and other techniques $[185,231]$. 
(a)

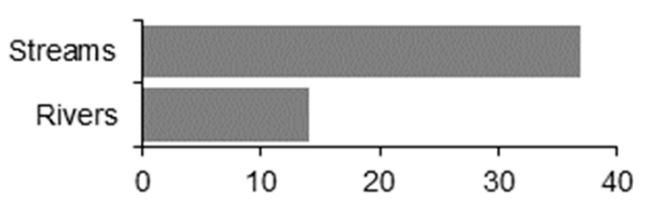

(b)

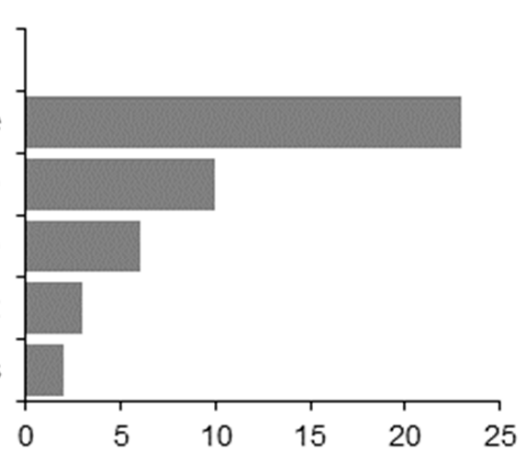

(c)

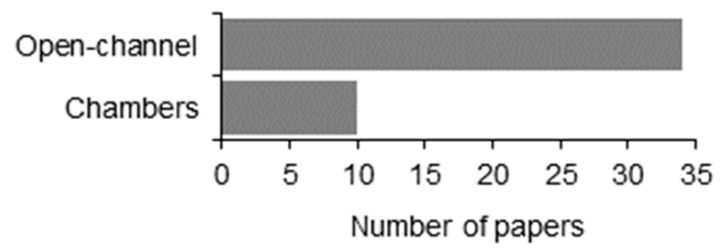

Figure 9. Representation of the (a) lotic systems, (b) methodological approaches, and (c) general methods used in field studies addressing ecosystem metabolism as a bioassessment tool $(n=44)$. Several studies were carried out in both streams and rivers and so the sum of the studies across systems surpasses the number of field studies.

(a)

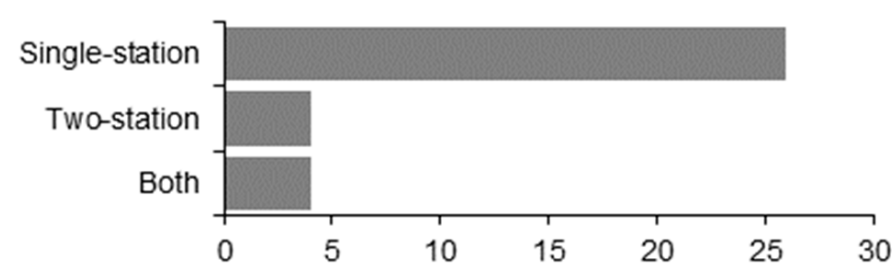

(b)

(c)
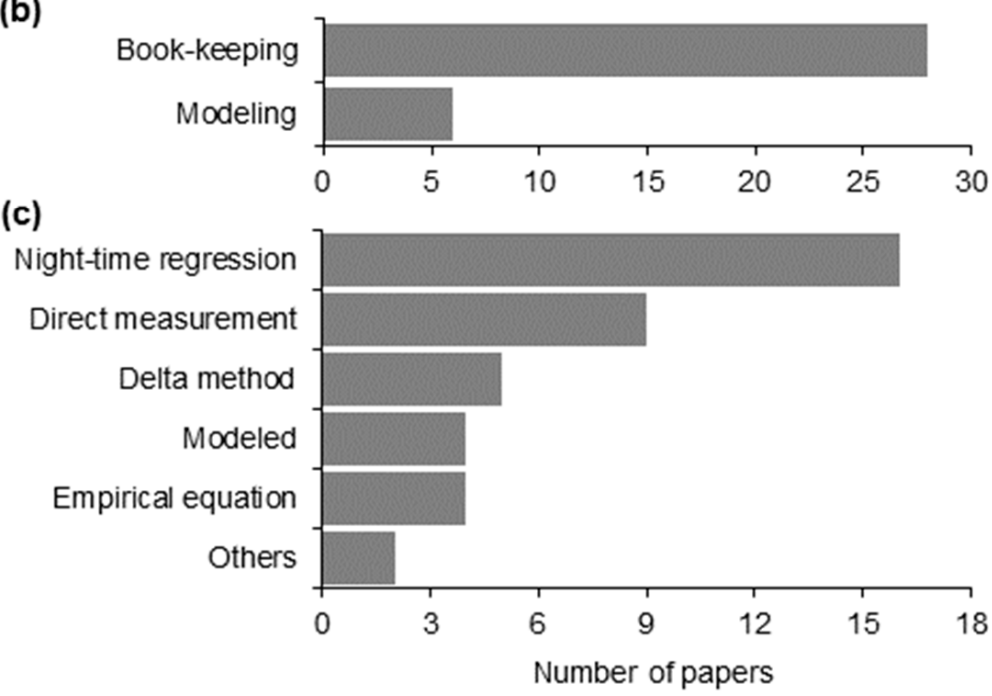

Figure 10. Procedures used in field studies using the open-channel method $(n=34)(\mathbf{a})$ to obtain the field data of DO, (b) to compute metabolic parameters, and (c) to estimate the reaeration rates. 
Most studies using the chambers method measured DO (8), except for two that used the resazurin-resorufin (Raz-Rru) method [232] or determined the microbial enzymatic activity on substrates [233] (Table S4). Most studies performed in situ measurements (7), while three made the measurements in a laboratory. The substrata were variable and included mineral substrata of distinct sizes and organic substrata, such as litter and periphyton (Table S4). Half of the studies (5) estimated GPP and community respiration using light and dark measures, and the other half only estimated community respiration in the dark (Table S4).

Most of the studies that assessed the usefulness of litter decomposition as a bioassessment tool found it to be effective in discriminating environmental change (i.e., impairment or recovery; 54 studies (76\%)) (Figure 11a, Table S3). Nine studies found that litter decomposition was non-effective as a bioassessment tool, and eight studies did not find clear evidence of the effectiveness of litter decomposition to detect environmental change (Figure 11a), with some of the reasons being season-dependency [234], a short incubation time [235], high habitat heterogeneity [208], context-dependency [236], or a small effect size [237] (Table S3). Similarly, of the 43 studies that assessed the effectiveness of the ecosystem metabolism as a bioassessment tool, $32(74 \%)$ found it to be effective in discriminating environmental change (Figure 11b, Table S4). Five studies found that ecosystem metabolism was non-effective as a bioassessment tool, and six studies did not find clear evidence of effectiveness (Figure 11b), with the main reasons being a lack of real control sites (e.g., [208,238]) or weak environmental change (e.g., [207,239]).
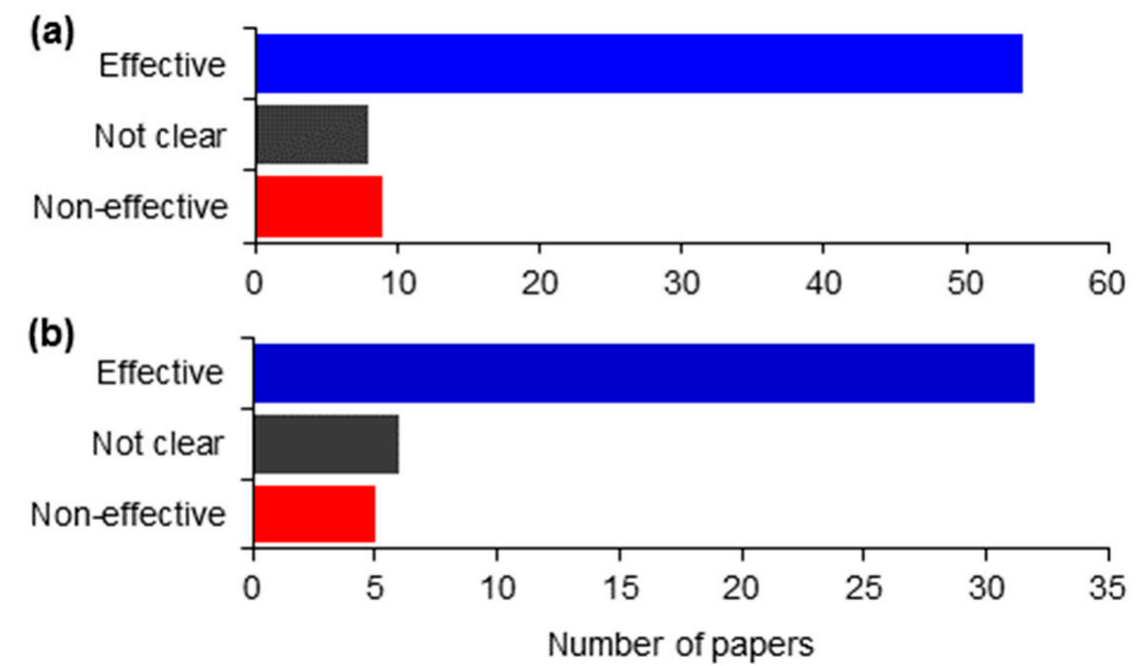

Figure 11. Main conclusion about the effectiveness of (a) organic matter decomposition $(n=71$; field studies that did not discriminate the effectiveness of organic matter decomposition from that of other functional indicators were excluded, $n=4$; Table S3) and (b) ecosystem metabolism ( $n=43)$ as bioassessment tools of stream functional integrity in bioassessment studies.

The effectiveness of organic matter decomposition and ecosystem metabolism as bioassessment tools varied between types of environmental change (Figure 12). In the case of environmental changes addressed by $\geq 2$ papers, organic matter decomposition was $100 \%$ efficient at detecting the effects of multiple stressors (7 studies), acidification (7), and restoration (3) (Figure 12a), whereas ecosystem metabolism was 100\% efficient at detecting the effects of hydromorphologic pressures (3 studies) and restoration (3) (Figure 12b). For the remaining types of environmental changes, the effectiveness of organic matter decomposition and ecosystem metabolism as bioassessment tools varied between $50 \%$ and $82 \%$ (Figure 12). Particularly interestingly was the fact that both organic matter decomposition $[207,216,217]$ and ecosystem metabolism [240-242] were effective in detecting the effects of restoration practices. Despite the low number of studies, this result suggests that these ecosystem functions may be useful indicators for the evaluation of restoration practices. However, 
we cannot rule out the possibility that studies showing effectiveness are more likely to be published than studies finding a lack of effectiveness.

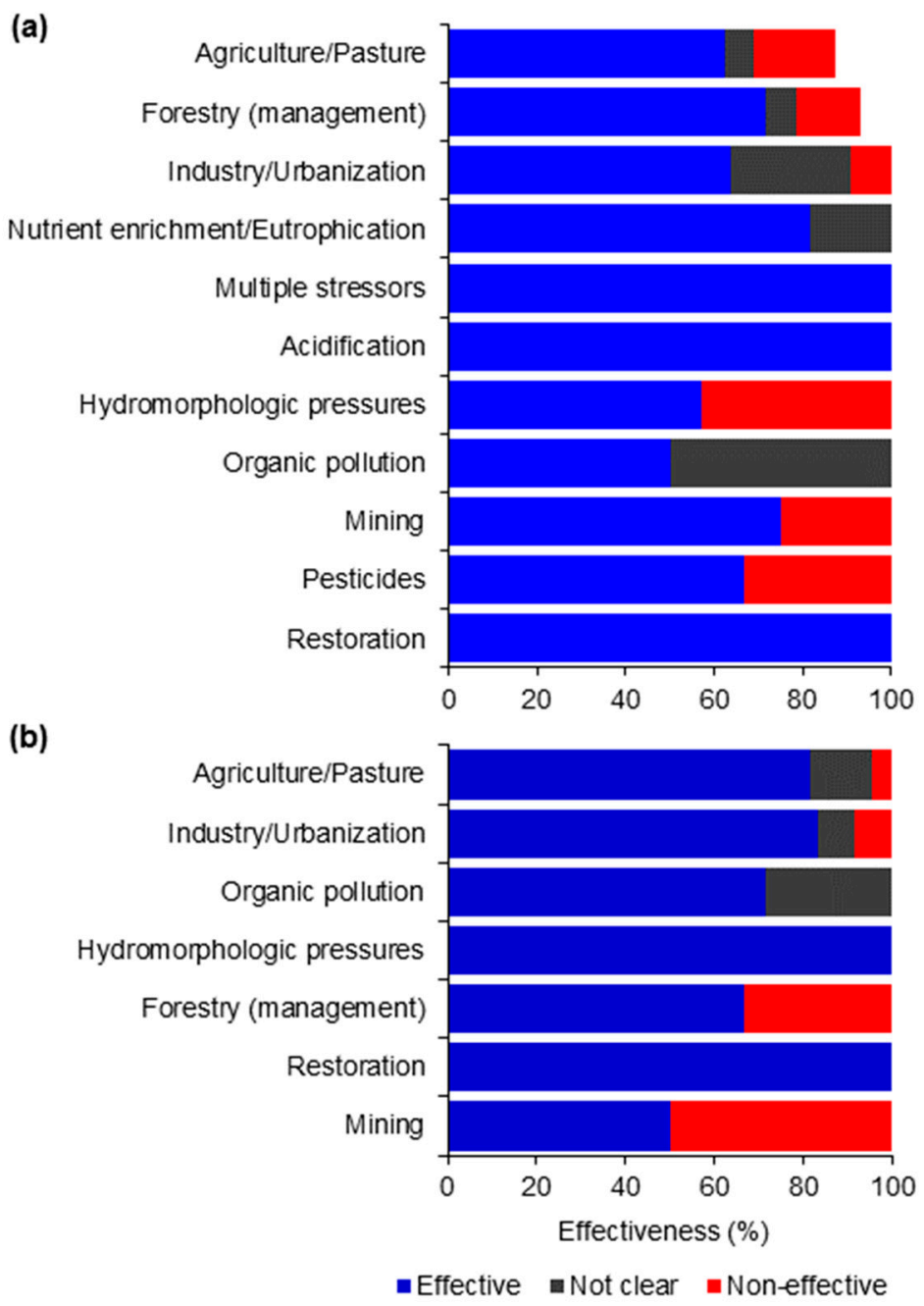

Figure 12. Effectiveness of the (a) organic matter decomposition and (b) ecosystem metabolism as bioassessment tools for each type of environmental change; only environmental changes addressed in $\geq 2$ papers are shown. The first two types of environmental change in panel (a) do not reach $100 \%$ due to the absence of four field studies that did not discriminate the effectiveness of organic matter decomposition from that of other functional indicators (Table S3). The types of environmental change are sorted by the number of papers in which they were addressed (see Figure 4).

\section{Incorporation of Functional Indicators into Official Bioassessment Programs}

Many stream and river researchers have called for the use of functional indicators in ecosystem bioassessment since the turn of the millennium $[1,10,12,13,210,243,244]$. In fact, there is a growing number of studies that report on the use of functional indicators in ecosystem bioassessment (Section 4), but their uptake in standard regional or national bioassessment programs has generally been slow. This is perhaps changing.

New Zealand has been quick to adopt ecosystem functions for inclusion in bioassessment programs and is a model for their inclusion elsewhere. Recent changes in New Zealand's national environmental policy have recognized ecosystem health as a compulsory value of freshwater ecosystems and ecological functions as a key component of ecosystem health, alongside water quality, water quantity, habitat, and aquatic life [11]. Ecosystem metabolism has been included in this policy as one of the compulsory attributes to be measured, giving ecosystem metabolism a similar status to structural indicators based on 
fish, macroinvertebrates, macrophytes, deposited sediment, dissolved reactive phosphorus, and DO. Local government agencies in New Zealand, who are responsible for environmental bioassessment and reporting, have shown an interest in the use of functional indicators for some time and helped to fund the development of the framework presented in Young et al. [13]. The inclusion of ecosystem metabolism in recent policy changes has led to an increase in interest and demand for guidance on measurement approaches and more resources will be required to implement the policy changes.

Using the criteria described in Young et al. [13], the analysis of metabolism measurements as part of regular regional bioassessment and reporting programs has identified sites ranging from poor to good ecosystem health [236,245-248]. Ecosystem metabolism has also been considered a useful tool for assessing the effectiveness of stream restoration [249]. Increases in shading from riparian plantings are expected to reduce GPP back to baseline levels. Reductions in inputs of organic waste are expected to reduce rates of ER back to baseline levels, while the restoration of riparian zones is expected to result in more natural levels of organic matter inputs, potentially increasing rates of ER in streams that are organic matter deficient. However, Doehring et al. [207] found no consistent evidence of changes in ecosystem metabolism among 11 pairs of sites with and without riparian buffers. They considered that the scale of riparian plantings (between 196-1600 $\mathrm{m}$ in length) was insufficient to affect stream metabolism, given that the buffers represented only a small proportion $(0.1-1.7 \%)$ of the total upstream stream length.

The value of including organic matter decomposition in monitoring programs has been recognized in New Zealand, but it has been difficult to encourage the use of further functional indicators when bioassessment budgets are already stretched. Initial trials of leaf litter decomposition as an indicator of stream functional integrity were hampered by leaf litter availability and the perceived variability in leaf litter chemical composition, even within a single species. Subsequent trials of standardized substrates (wood sticks and cotton strips) showed more promise, but the results were sometimes difficult to interpret $[65,250,251]$.

In South East Queensland, Australia, freshwater bioassessment incorporates 22 indicators across five indicator groups, including ecosystem metabolism, with regular bioassessment at over 120 stream sites throughout the region [210]. GPP is primarily influenced by water chemistry and riparian condition, while ER reflects the water and sediment chemistry. The bioassessment information is used to develop report cards that summarize the ecosystem health of stream sites for local politicians and the wider community and have been instrumental in growing awareness among the public of the connections between land management and the health of the region's waterways [210].

In France, the national agency for water and aquatic ecosystems (ONEMA) seems to be open to the incorporation of leaf litter decomposition into bioassessment programs. Colas et al. [252] reported the case where practitioners of water agencies collaborated with researchers to test the use of leaf litter decomposition as an indicator of hydromorphological disturbance and water chemical quality. For this, Alnus glutinosa leaves were enclosed in fine- and coarse-mesh bags and incubated in 82 stream sites distributed throughout France. According to the authors, the interaction between the researchers and river managers promoted the direct transfer of a bioassessment tool based on leaf litter decomposition to stakeholders, which may promote its inclusion in future bioassessment programs [252].

In other places, however, the incorporation of indicators of stream functional integrity in bioassessment programs is hindered by multiple factors. For instance, in Portugal, the effort to implement structural indicators is already considerable (in terms of the budget and human resources), there is still much to do (for instance, extend bioassessment to all water bodies), and it is already very difficult to meet the deadlines of the Water Framework Directive. Thus, providing additional effort to incorporate functional indicators is not feasible at present.

Despite the difficulties in incorporating indicators of stream functional integrity in large scale bioassessment programs, these can be particularly useful in bioassessment programs at smaller scales. Examples include the evaluation of the effects of stream restoration practices [66,207,216,240-242] or of particular point source pollution (pesticide spill [253], wastewater treatment plant [110,254]). 
In conclusion, organic matter decomposition and ecosystem metabolism have been shown to be widely effective in detecting the environmental changes caused by anthropogenic activities. Therefore, these two functions have great potential as indicators of stream functional integrity. Incorporating these functions in stream bioassessment programs is an essential step toward the improvement of the management and conservation of running water ecosystems.

Supplementary Materials: The following are available online at http:/www.mdpi.com/2073-4441/12/12/3523/s1. Figure S1: Overview of the literature search for studies addressing the use of organic matter decomposition as a bioassessment tool of stream functional integrity, the studies screening, and the selection. Figure S2: Overview of the literature search for studies addressing the use of ecosystem metabolism as a bioassessment tool of stream functional integrity, the studies screening, and the selection. Table S1: Information extracted from the studies addressing the use of organic matter decomposition as a bioassessment tool of stream functional integrity. For review studies, only the information marked with an "*” was extracted. Table S2: Information extracted from the studies addressing the use of ecosystem metabolism as a bioassessment tool of stream functional integrity. For review studies, only the information marked with an "** was extracted. Table S3: Matrix of studies addressing the use of organic matter decomposition as a bioassessment tool of stream functional integrity over the last two decades. For the definition of the extracted information, see Table S1. Table S4: Matrix of studies addressing the use of ecosystem metabolism as a bioassessment tool of stream functional integrity over the last two decades. For the definition of the extracted information, see Table S2. References [255-316] are cited in the supplementary materials.

Author Contributions: V.F. conceived the review. All authors decided on the structure of the review and wrote specific sections. V.F. performed the systematic literature review addressing litter decomposition. D.v.S. performed the systematic literature review addressing stream metabolism; A.E. and R.Y. helped with the study selection and data extraction. All authors have read and agreed to the published version of the manuscript.

Funding: This study was financed by the Portuguese Foundation for Science and Technology (FCT) through the strategic project UIDP/04292/2020 granted to MARE-Marine and Environmental Sciences Centre. Financial support granted by the FCT to V.F. (CEECIND/02484/2018) is also acknowledged. D.v.S. is a Serra Húnter Fellow and was additionally supported by the Catalan Government through the FORESTREAM (Forest and Stream Ecological Links: Watershed Management and Restoration) grant (2017 SGR 976).

Conflicts of Interest: The authors declare no conflict of interest.

\section{References}

1. Gessner, M.O.; Chauvet, E. A case for using litter breakdown to assess functional stream integrity. Ecol. Appl. 2002, 12, 498-510. [CrossRef]

2. European Commission. Directive 2000/60/EC of the European Parliament and of the Council of 23 October 2000 establishing a framework for Community action in the field of water policy. Off. J. European Comm. 2000, L327, 1-72.

3. Barbour, M.T.; Gerritsen, J.; Snyder, B.D.; Stribling, J.B. Rapid Bioassessment Protocols for Use in Streams and Wadeable Rivers: Periphyton, Benthic Macroinvertebrates and Fish, 2nd ed.; EPA 841-B-99-002; U.S. Environmental Protection Agency, Office of Water: Washington, DC, USA, 1999; p. 337.

4. Sandin, L.; Solimini, A.G. Freshwater ecosystem structure-function relationships: From theory to application. Freshwat. Biol. 2009, 54, 2017-2024. [CrossRef]

5. Feckler, A.; Bundschuh, M. Decoupled structure and function of leaf-associated microorganisms under anthropogenic pressure: Potential hurdles for environmental monitoring. Freshw. Sci. 2020, 39. [CrossRef]

6. Verdonschot, P.F.M.; Lee, G.H. Perspectives on the functional assessment of multi-stressed stream ecosystems. Freshwat. Sci. 2020, 39. [CrossRef]

7. McKie, B.G.; Malmqvist, B. Assessing ecosystem functioning in streams affected by forest management: Increased leaf decomposition occurs without changes to the composition of benthic assemblages. Freshwat. Biol. 2009, 54, 2086-2100. [CrossRef]

8. Riipinen, M.P.; Davy-Bowker, J.; Dobson, M. Comparison of structural and functional stream assessment methods to detect changes in riparian vegetation and water pH. Freshwat. Biol. 2009, 54, 2127-2138. [CrossRef]

9. Capon, S.J.; Chambers, L.E.; Mac Nally, R.; Naiman, R.J.; Davies, P.; Marshall, N.; Pittock, J.; Reid, M.; Capon, T.; Douglas, M.; et al. Riparian ecosystems in the 21st century: Hotspots for climate change adaptation? Ecosystems 2013, 16, 359-381. [CrossRef] 
10. Jackson, M.C.; Weyl, O.L.F.; Altermatt, F.; Durance, I.; Friberg, N.; Dumbrell, A.J. Recommendations for the next generation of global freshwater biological monitoring tools. Adv. Ecol. Res. 2016, 55, 615-636. [CrossRef]

11. New Zealand Ministry for the Environment. National Policy Statement for Freshwater Management 2020; New Zealand Government: Wellington, New Zealand, August 2020; p. 70.

12. von Schiller, D.; Acuña, V.; Aristi, I.; Arroita, M.; Basaguren, A.; Bellin, A.; Boyero, L.; Butturini, A.; Ginebreda, A.; Kalogianni, E.; et al. River ecosystem processes: A synthesis of approaches, criteria of use and sensitivity to environmental stressors. Sci. Total Environ. 2017, 596, 465-480. [CrossRef]

13. Young, R.G.; Matthaei, C.D.; Townsend, C.R. Organic matter breakdown and ecosystem metabolism: Functional indicators for assessing river ecosystem health. J. N. Am. Benthol. Soc. 2008, 27, 605-625. [CrossRef]

14. Bonada, N.; Prat, N.; Resh, V.H.; Statzner, B. Developments in aquatic insect biomonitoring: A comparative analysis of recent approaches. Ann. Rev. Entomol. 2006, 51, 495-523. [CrossRef] [PubMed]

15. Cummins, K.W.; Klug, M.J. Feeding ecology of stream invertebrates. Annu. Rev. Ecol. Syst. 1979, 10, $147-172$. [CrossRef]

16. Gessner, M.O. Differences in processing dynamics of fresh and dried leaf litter in a stream ecosystem. Freshwat. Biol. 1991, 26, 387-398. [CrossRef]

17. Canhoto, C.; Graça, M.A.S. Decomposition of Eucalyptus globulus leaves and three native leaf species (Alnus glutinosa, Castanea sativa and Quercus faginea) in a Portuguese low order stream. Hydrobiologia 1996, 333, 79-85. [CrossRef]

18. France, R.; Culbert, H.; Freeborough, C.; Peters, R. Leaching and early mass loss of boreal leaves and wood in oligotrophic water. Hydrobiologia 1997, 345, 209-214. [CrossRef]

19. Campbell, I.C.; James, K.R.; Hart, B.T.; Devereaux, A. Allochthonous coarse particulate organic material in forest and pasture reaches of two south-eastern Australian streams: II. Litter processing. Freshwat. Biol. 1992, 27, 353-365. [CrossRef]

20. Taylor, B.R.; Bärlocher, F. Variable effects of air-drying on leaching losses from tree leaf litter. Hydrobiologia 1996, 325, 173-182. [CrossRef]

21. Quinn, J.M.; Burrell, G.P.; Parkyn, S.M. Influences of leaf toughness and nitrogen content on in-stream processing and nutrient uptake by litter in a Waikato, New Zealand, pasture stream and streamside channels. N. Z. J. Mar. Freshwat. Res. 2000, 34, 253-271. [CrossRef]

22. Bärlocher, F. Fungal colonization of fresh and dried leaves in the river Teign (Devon, England). Nova Hedwigia 1991, 52, 349-357.

23. Gessner, M.O.; Dobson, M. Colonization of fresh and dried leaf litter by lotic macroinvertebrates. Internat. Verein. Theor. Angew. Limnol. Verh. 1994, 25, 1544. [CrossRef]

24. Chergui, H.; Pattee, E. The influence of season on the breakdown of submerged leaves. Arch. Hydrobiol. 1990, 120, 1-12.

25. Gulis, V.; Rong, S.; Kuehn, K.A. Fungal decomposers in freshwater environments. In The Structure and Function of Aquatic Microbial Communities; Hurst, C.J., Ed.; Springer: Cham, Switzerland, 2019; pp. 121-155.

26. Baldy, V.; Gessner, M.O.; Chauvet, E. Bacteria, fungi and the breakdown of leaf litter in a large river. Oikos 1995, 74, 93-102. [CrossRef]

27. Pascoal, C.; Cássio, F. Contribution of fungi and bacteria to leaf litter decomposition in a polluted river. Appl. Environ. Microbiol. 2004, 70, 5266-5273. [CrossRef]

28. Gessner, M.O.; Chauvet, E. Importance of stream microfungi in controlling breakdown rates of leaf litter. Ecology 1994, 75, 1807-1817. [CrossRef]

29. Arroita, M.; Aristi, I.; Flores, L.; Larrañaga, A.; Díez, J.; Mora, J.; Romaní, A.M.; Elosegi, A. The use of wooden sticks to assess stream ecosystem functioning: Comparison with leaf breakdown rates. Sci. Total Environ. 2012, 440, 115-122. [CrossRef] [PubMed]

30. Chauvet, E.; Ferreira, V.; Giller, P.S.; McKie, B.G.; Tiegs, S.D.; Woodward, G.; Elosegi, A.; Dobson, M.; Fleituch, T.; Graça, M.A.S.; et al. Litter decomposition as an indicator of stream ecosystem functioning at local-to-continental scales: Insights from the European RivFunction project. Adv. Ecol. Res. 2016, 55, 99-182. [CrossRef]

31. Hieber, M.; Gessner, M.O. Contribution of stream detrivores, fungi, and bacteria to leaf breakdown based on biomass estimates. Ecology 2002, 83, 1026-1038. [CrossRef] 
32. Nikolcheva, L.G.; Bärlocher, F. Taxon-specific fungal primers reveal unexpectedly high diversity during leaf decomposition in a stream. Mycol. Prog. 2004, 3, 41-49. [CrossRef]

33. Sampaio, A.; Cortes, R.; Leão, C. Yeast and macroinvertebrate communities associated with leaf litter decomposition in a second order stream. Internat. Rev. Hydrobiol. 2004, 89, 453-466. [CrossRef]

34. Sampaio, A.; Sampaio, J.P.; Leão, C. Dynamics of yeast populations recovered from decaying leaves in a nonpolluted stream: A 2-year study on the effects of leaf litter type and decomposition time. FEMS Yeast Res. 2007, 7, 595-603. [CrossRef] [PubMed]

35. Ribblett, S.G.; Palmer, M.A.; Wayne Coats, D. The importance of bacterivorous protists in the decomposition of stream leaf litter. Freshwat. Biol. 2005, 50, 516-526. [CrossRef]

36. Bärlocher, F.; Stewart, M.; Ryder, D.S. Processing of Eucalyptus viminalis leaves in Australian streams-importance of aquatic hyphomycetes and zoosporic fungi. Fund. Appl. Limnol./Arch. Hydrobiol. 2012, 179, 305-319. [CrossRef]

37. Howard-Parker, B.; White, B.; Halvorson, H.M.; Evans-White, M.A. Light and dissolved nutrients mediate recalcitrant organic matter decomposition via microbial priming in experimental streams. Freshwat. Biol. 2020, 65, 1189-1199. [CrossRef]

38. Elosegi, A.; Nicolás, A.; Richardson, J.S. Priming of leaf litter decomposition by algae seems of minor importance in natural streams during autumn. PLoS ONE 2018, 13, e0200180. [CrossRef]

39. Halvorson, H.M.; Barry, J.R.; Lodato, M.B.; Findlay, R.H.; Francoeur, S.N.; Kuehn, K.A. Periphytic algae decouple fungal activity from leaf litter decomposition via negative priming. Funct. Ecol. 2019, 33, 188-201. [CrossRef]

40. Baldy, V.; Gessner, M.O. Towards a budget of leaf litter decomposition in a first-order woodland stream. Compt. Rendus Acad. Sci.-Sci. Vie 1997, 320, 747-758. [CrossRef]

41. Baldy, V.; Gobert, V.; Guérold, F.; Chauvet, E.; Lambrigot, D.; Charcosset, J.Y. Leaf litter breakdown budgets in streams of various trophic status: Effects of dissolved inorganic nutrients on microorganisms and invertebrates. Freshwat. Biol. 2007, 52, 1322-1335. [CrossRef]

42. Gulis, V.; Suberkropp, K. Leaf litter decomposition and microbial activity in nutrient-enriched and unaltered reaches of a headwater stream. Freshwat. Biol. 2003, 48, 123-134. [CrossRef]

43. Graça, M.A.S. The role of invertebrates on leaf litter decomposition in streams-a review. Internat. Rev. Hydrobiol. 2001, 86, 383-393. [CrossRef]

44. Dangles, O.; Gessner, M.O.; Guérold, F.; Chauvet, E. Impacts of stream acidification on litter breakdown: Implications for assessing ecosystem functioning. J. Appl. Ecol. 2004, 41, 365-378. [CrossRef]

45. Hagen, E.M.; Webster, J.R.; Benfield, E.F. Are leaf breakdown rates a useful measure of stream integrity along an agricultural landuse gradient? J. N. Am. Benthol. Soc. 2006, 25, 330-343. [CrossRef]

46. Piscart, C.; Genoel, R.; Doledec, S.; Chauvet, E.; Marmonier, P. Effects of intense agricultural practices on heterotrophic processes in streams. Environ. Poll. 2009, 157, 1011-1018. [CrossRef] [PubMed]

47. Azevedo-Pereira, H.V.S.; Graça, M.A.S.; González, J.M. Life history of Lepidostoma hirtum in an Iberian stream and its role in organic matter processing. Hydrobiologia 2006, 559, 183-192. [CrossRef]

48. Ferreira, V.; Raposeiro, P.M.; Pereira, A.; Cruz, A.M.; Costa, A.C.; Graça, M.A.S.; Gonçalves, V. Leaf litter decomposition in remote oceanic island streams is driven by microbes and depends on litter quality and environmental conditions. Freshwat. Biol. 2016, 61, 783-799. [CrossRef]

49. Gonçalves, J.F., Jr.; Graça, M.A.S.; Callisto, M. Leaf-litter breakdown in 3 streams in temperate, Mediterranean, and tropical Cerrado climates. J. N. Am. Benthol. Soc. 2006, 25, 344-355. [CrossRef]

50. Gonçalves, J.F., Jr.; Graça, M.A.S.; Callisto, M. Litter decomposition in a Cerrado savannah stream is retarded by leaf toughness, low dissolved nutrients and a low density of shredders. Freshwat. Biol. 2007, 52, 1440-1451. [CrossRef]

51. Ferreira, V.; Graça, M.A.S.; de Lima, J.L.M.P.; Gomes, R. Role of physical fragmentation and invertebrate activity in the breakdown rate of leaves. Arch. Hydrobiol. 2006, 165, 493-513. [CrossRef]

52. Bastias, E.; Bolivar, M.; Ribot, M.; Peipoch, M.; Thomas, S.A.; Sabater, F.; Martí, E. Spatial heterogeneity in water velocity drives leaf litter dynamics in streams. Freshwat. Biol. 2020, 65, 435-445. [CrossRef]

53. Ostrofsky, M.L. Relationship between chemical characteristics of autumn-shed leaves and aquatic processing rates. J. N. Am. Benthol. Ass. 1997, 16, 750-759. [CrossRef] 
54. Jabiol, J.; Lecerf, A.; Lamothe, S.; Gessner, M.O.; Chauvet, E. Litter quality modulates effects of dissolved nitrogen on leaf decomposition by stream microbial communities. Microb. Ecol. 2019, 77, 959-966. [CrossRef] [PubMed]

55. LeRoy, C.J.; Whitham, T.G.; Wooley, S.C.; Marks, J.C. Within-species variation in foliar chemistry influences leaf-litter decomposition in a Utah river. J. N. Am. Benthol. Soc. 2007, 26, 426-438. [CrossRef]

56. Lecerf, A.; Chauvet, E. Intraspecific variability in leaf traits strongly affects alder leaf decomposition in a stream. Basic Appl. Ecol. 2008, 9, 598-605. [CrossRef]

57. LeRoy, C.J.; Wooley, S.C.; Lindroth, R.L. Genotype and soil nutrient environment influence aspen litter chemistry and in-stream decomposition. Freshwat. Sci. 2012, 31, 1244-1253. [CrossRef]

58. Graça, M.A.S.; Poquet, J.M. Do climate and soil influence phenotypic variability in leaf litter, microbial decomposition and shredder consumption? Oecologia 2014, 174, 1021-1032. [CrossRef]

59. Irons, J.G., III; Bryant, J.P.; Oswood, M.W. Effects of moose browsing on decomposition rates of birch leaf litter in a subarctic stream. Can. J. Fish. Aquat. Sci. 1991, 48, 442-444. [CrossRef]

60. Martinsen, G.D.; Driebe, E.M.; Whitham, T.G. Indirect interactions mediated by changing plant chemistry:beaver browsing benefits beetles. Ecology 1998, 79, 92-200. [CrossRef]

61. Pazianoto, L.H.R.; Solla, A.; Ferreira, V. Infection of sweet chestnut trees by a pathogenic oomycete influences leaf litter decomposition more than water temperature rise. Fungal Ecol. 2019, 41, 269-278. [CrossRef]

62. Suomela, J.; Ayres, M.P. Within-tree and among-tree variation in leaf characteristics of mountain birch and its implications for herbivory. Oikos 1994, 70, 212-222. [CrossRef]

63. Henriksson, J.; Haukioja, E.; Ossipov, V.; Ossipova, S.; Sillanpää, S.; Kapari, L.; Pihlaja, K. Effects of host shading on consumption and growth of the geometrid Epirrita autumnata: Interactive roles of water, primary and secondary compounds. Oikos 2003, 103, 3-16. [CrossRef]

64. Spänhoff, B.; Augspurger, C.; Küsel, K. Comparing field and laboratory breakdown rates of coarse particulate organic matter: Sediment dynamics mask the impacts of dissolved nutrients on CPOM mass loss in streams. Aquat. Sci. 2007, 69, 495-502. [CrossRef]

65. Young, R.G.; Collier, K.J. Contrasting responses to catchment modification among a range of functional and structural indicators of river ecosystem health. Freshwat. Biol. 2009, 54, 2155-2170. [CrossRef]

66. Frainer, A.; Moretti, M.S.; Xu, W.; Gessner, M.O. No evidence for leaf-trait dissimilarity effects on litter decomposition, fungal decomposers, and nutrient dynamics. Ecology 2015, 96, 550-561. [CrossRef]

67. Zhang, M.; Cheng, X.; Geng, Q.; Shi, Z.; Luo, Y.; Xu, X. Leaf litter traits predominantly control litter decomposition in streams worldwide. Glob. Ecol. Biogeogr. 2019, 28, 1469-1486. [CrossRef]

68. Graça, M.A.S.; Pozo, J.; Canhoto, C.; Elosegi, A. Effects of Eucalyptus plantations on detritus, decomposers, and detritivores in streams. Sci. World J. 2002, 2, 1173-1185. [CrossRef] [PubMed]

69. Hladyz, S.; Åbjörnsson, K.; Giller, P.S.; Woodward, G. Impacts of an aggressive riparian invader on community structure and ecosystem functioning in stream food webs. J. Appl. Ecol. 2011, 48, 443-452. [CrossRef]

70. Kominoski, J.S.; Follstad Shah, J.J.; Canhoto, C.; Fischer, D.G.; Giling, D.P.; González, E.; Griffiths, N.A.; Larrañaga, A.; LeRoy, C.J.; Mineau, M.M.; et al. Forecasting functional implications of global changes in riparian plant communities. Front. Ecol. Environ. 2013, 11, 423-432. [CrossRef]

71. Ferreira, V.; Castela, J.; Rosa, P.; Tonin, A.M.; Boyero, L.; Graça, M.A.S. Aquatic hyphomycetes, benthic macroinvertebrates and leaf litter decomposition in streams naturally differing in riparian vegetation. Aquat. Ecol. 2016, 50, 711-725. [CrossRef]

72. Danger, M.; Gessner, M.O.; Bärlocher, F. Ecological stoichiometry of aquatic fungi: Current knowledge and perspectives. Fungal Ecol. 2016, 19, 100-111. [CrossRef]

73. Grattan, R.M.; Suberkropp, K. Effects of nutrient enrichment on yellow poplar leaf decomposition and fungal activity in streams. J. N. Am. Benthol. Soc. 2001, 20,33-43. [CrossRef]

74. Suberkropp, K.; Chauvet, E. Regulation of leaf breakdown by fungi in streams: Influences of water chemistry. Ecology 1995, 76, 1433-1445. [CrossRef]

75. Rosemond, A.D.; Benstead, J.P.; Bumpers, P.M.; Gulis, V.; Kominoski, J.S.; Manning, D.W.; Suberkropp, K.; Wallace, J.B. Experimental nutrient additions accelerate terrestrial carbon loss from stream ecosystems. Science 2015, 347, 1142-1145. [CrossRef] [PubMed]

76. Niyogi, D.K.; Simon, K.; Townsend, C.R. Breakdown of tussock grass in streams along a gradient of agricultural development in New Zealand. Freshwat. Biol. 2003, 48, 1698-1708. [CrossRef] 
77. Gulis, V.; Ferreira, V.; Graça, M.A.S. Stimulation of leaf litter decomposition and associated fungi and invertebrates by moderate eutrophication: Implications for stream assessment. Freshwat. Biol. 2006, 51, 1655-1669. [CrossRef]

78. Ferreira, V.; Castagneyrol, B.; Koricheva, J.; Gulis, V.; Chauvet, E.; Graça, M.A.S. A meta-analysis of the effects of nutrient enrichment on litter decomposition in streams. Biol. Rev. 2015, 90, 669-688. [CrossRef] [PubMed]

79. Lecerf, A.; Usseglio-Polatera, P.; Charcosset, J.Y.; Lambrigot, D.; Bracht, B.; Chauvet, E. Assessment of functional integrity of eutrophic streams using litter breakdown and benthic macroinvertebrates. Arch. Hydrobiol. 2006, 165, 105-126. [CrossRef]

80. Woodward, G.; Gessner, M.O.; Giller, P.S.; Gulis, V.; Hladyz, S.; Lecerf, A.; Malmqvist, B.; McKie, B.G.; Tiegs, S.D.; Cariss, H.; et al. Continental-scale effects of nutrient pollution on stream ecosystem functioning. Science 2012, 336, 1438-1440. [CrossRef]

81. Brown, J.H.; Gillooly, J.F.; Allen, A.P.; Savage, V.M.; West, G.B. Toward a metabolic theory of ecology. Ecology 2004, 85, 1771-1789. [CrossRef]

82. Englert, D.; Zubrod, J.P.; Schulz, R.; Bundschuh, M. Variability in ecosystem structure and functioning in a low order stream: Implications of land use and season. Sci. Total Environ. 2015, 538, 341-349. [CrossRef]

83. Fabre, E.; Chauvet, E. Leaf breakdown along an altitudinal stream gradient. Arch. Hydrobiol. 1998, 141, 167-179. [CrossRef]

84. Taylor, B.R.; Chauvet, E.E. Relative influence of shredders and fungi on leaf litter decomposition along a river altitudinal gradient. Hydrobiologia 2014, 721, 239-250. [CrossRef]

85. Boyero, L.; Pearson, R.G.; Gessner, M.O.; Barmuta, L.A.; Ferreira, V.; Graça, M.A.S.; Dudgeon, D.; Boulton, A.J.; Callisto, M.; Chauvet, E.; et al. A global experiment suggests climate warming will not accelerate litter decomposition in streams but might reduce carbon sequestration. Ecol. Lett. 2011, 14, 289-294. [CrossRef] [PubMed]

86. Tiegs, S.D.; Costello, D.M.; Isken, M.W.; Woodward, G.; McIntyre, P.B.; Gessner, M.O.; Chauvet, E.; Griffiths, N.A.; Flecker, A.S.; Acuña, V.; et al. Global patterns and drivers of ecosystem functioning in rivers and riparian zones. Sci. Adv. 2019, 5, eaav0486. [CrossRef] [PubMed]

87. Jinggut, T.; Yule, C.M. Leaf-litter breakdown in streams of East Malaysia (Borneo) along an altitudinal gradient: Initial nitrogen content of litter limits shredder feeding. Freshwat. Sci. 2015, 34, 691-701. [CrossRef]

88. Ferreira, V.; Canhoto, C. Future increase in temperature might stimulate litter decomposition in temperate cold water streams - evidence from a stream manipulation experiment. Freshwat. Biol. 2015, 60, 881-892. [CrossRef]

89. Gonçalves, A.L.; Graça, M.A.S.; Canhoto, C. The effect of temperature on leaf decomposition and diversity of associated aquatic hyphomycetes depends on the substrate. Fungal Ecol. 2013, 6, 546-553. [CrossRef]

90. Ferreira, V.; Chauvet, E.; Canhoto, C. Effects of experimental warming, litter species, and presence of macroinvertebrates on litter decomposition and associated decomposers in a temperate mountain stream. Can. J. Fish. Aquat. Sci. 2015, 72, 206-216. [CrossRef]

91. Medeiros, A.O.; Pascoal, C.; Graça., M.A.S. Diversity and activity of aquatic fungi under low oxygen conditions. Freshwat. Biol. 2009, 54, 142-149. [CrossRef]

92. González, J.M.; Graça, M.A.S. Conversion of leaf litter to secondary production by a shredding caddis-fly. Freshwat. Biol. 2003, 48, 1578-1592. [CrossRef]

93. Wood-Eggenschwiler, S.; Bärlocher, F. Aquatic hyphomycetes in sixteen streams in France, Germany and Switzerland. Trans. Brit. Mycol. Soc. 1983, 81,371-379. [CrossRef]

94. Raviraja, N.S.; Sridhar, K.R.; Bärlocher, F. Fungal species richness in Western Ghat streams (southern India): Is it related to $\mathrm{pH}$, temperature or altitude. Fungal Div. 1998, 1, 179-191.

95. Rajashekhar, M.; Kaveriappa, K.M. Diversity of aquatic hyphomycetes in the aquatic ecosystems of the Western Ghats of India. Hydrobiologia 2003, 501, 167-177. [CrossRef]

96. Petrin, Z.; Englund, G.; Malmqvist, B. Contrasting effects of anthropogenic and natural acidity in streams: A meta-analysis. Proc. Royal Soc. B Biol. Sci. 2008, 275, 1143-1148. [CrossRef] [PubMed]

97. Cornut, J.; Clivot, H.; Chauvet, E.; Elger, A.; Pagnout, C.; Guérold, F. Effect of acidification on leaf litter decomposition in benthic and hyporheic zones of woodland streams. Water Res. 2012, 46, 6430-6444. [CrossRef] [PubMed]

98. Ferreira, V.; Guérold, F. Leaf litter decomposition as a bioassessment tool of acidification effects in streams: Evidence from a field study and meta-analysis. Ecol. Ind. 2017, 79, 382-390. [CrossRef] 
99. Colas, F.; Woodward, G.; Burdon, F.J.; Guérold, F.; Chauvet, E.; Cornut, J.; Cébron, A.; Clivot, H.; Danger, M.; Danner, M.C.; et al. Towards a simple global-standard bioassay for a key ecosystem process: Organic-matter decomposition using cotton strips. Ecol. Ind. 2019, 106, 105-466. [CrossRef]

100. Cook, A.R.; Hoellein, T.J. Environmental drivers of leaf breakdown in an urban watershed. Freshwat. Sci. 2016, 35, 311-323. [CrossRef]

101. Ferreira, V.; Graça, M.A.S. Do invertebrate activity and current velocity affect fungal assemblage structure in leaves? Internat. Rev. Hydrobiol. 2006, 91, 1-14. [CrossRef]

102. Pattee, E.; Maamri, A.; Chergui, H. Leaf litter processing and its agents in a temporary Moroccan river. Int. Ver. Theor. Angew. Limnol. Verh. 2001, 27, 3054-3057. [CrossRef]

103. Abril, M.; Muñoz, I.; Menéndez, M. Heterogeneity in leaf litter decomposition in a temporary Mediterranean stream during flow fragmentation. Sci. Total Environ. 2016, 553, 330-339. [CrossRef]

104. Arias-Real, R.; Muñoz, I.; Gutierrez-Cánovas, C.; Granados, V.; Lopez-Laseras, P.; Menéndez, M. Subsurface zones in intermittent streams are hotspots of microbial decomposition during the non-flow period. Sci. Total Environ. 2020, 703, 135485. [CrossRef] [PubMed]

105. Datry, T.; Corti, R.; Claret, C.; Philippe, M. Flow intermittence controls leaf litter breakdown in a French temporary alluvial river: The "drying memory". Aquat. Sci. 2011, 73, 471-483. [CrossRef]

106. Fritz, K.M.; Fulton, S.; Johnson, B.R.; Barton, C.D.; Jack, J.D.; Word, D.A.; Burke, R.A. Structural and functional characteristics of natural and constructed channels draining a reclaimed mountaintop removal and valley fill coal mine. J. N. Am. Benthol. Soc. 2010, 29, 673-689. [CrossRef]

107. Masese, F.O.; Kitaka, N.; Kipkemboi, J.; Gettel, G.M.; Irvine, K.; McClain, M.E. Litter processing and shredder distribution as indicators of riparian and catchment influences on ecological health of tropical streams. Ecol. Ind. 2014, 46, 23-37. [CrossRef]

108. Yule, C.M.; Gan, J.Y.; Jinggut, T.; Lee, K.V. Urbanization affects food webs and leaf-litter decomposition in a tropical stream in Malaysia. Freshwat. Sci. 2015, 34, 702-715. [CrossRef]

109. Tagliaferro, M.; Giorgi, A.; Torremorell, A.; Albariño, R. Urbanisation reduces litter breakdown rates and affects benthic invertebrate structure in Pampean streams. Internat. Rev. Hydrobiol. 2020, 105, $33-43$. [CrossRef]

110. Burdon, F.J.; Bai, Y.; Reyes, M.; Tamminen, M.; Staudacher, P.; Mangold, S.; Singer, H.; Räsänen, K.; Joss, A.; Tiegs, S.D.; et al. Stream microbial communities and ecosystem functioning show complex responses to multiple stressors in wastewater. Glob. Change Biol. 2020, 26, 6363-6382. [CrossRef]

111. Pascoal, C.; Pinho, M.; Cássio, F.; Gomes, P. Assessing structural and functional ecosystem condition using leaf breakdown: Studies on a polluted river. Freshwat. Biol. 2003, 48, 2033-2044. [CrossRef]

112. Castela, J.; Ferreira, V.; Graça, M.A.S. Evaluation of stream ecological integrity using litter decomposition and benthic invertebrates. Environ. Poll. 2008, 15, 440-449. [CrossRef]

113. Sabater, S.; Elosegi, A.; Ludwig, R. Framing biophysical and societal implications of multiple stressor effects on river networks. Sci. Total Environ. 2021, 753, 141973. [CrossRef]

114. Niyogi, D.K.; Harding, J.S.; Simon, K.S. Organic matter breakdown as a measure of stream health in New Zealand streams affected by acid mine drainage. Ecol. Ind. 2013, 24, 510-517. [CrossRef]

115. Ferreira, V.; Chauvet, E. Synergistic effects of water temperature and dissolved nutrients on litter decomposition and associated fungi. Glob. Change Biol. 2011, 17, 551-564. [CrossRef]

116. Fernandes, I.; Seena, S.; Pascoal, C.; Cássio, F. Elevated temperature may intensify the positive effects of nutrients on microbial decomposition in streams. Freshwat. Biol. 2014, 59, 2390-2399. [CrossRef]

117. Webster, J.R.; Benfield, E.F. Vascular plant breakdown in freshwater ecosystems. Annu. Rev. Ecol. Evol. Syst. 1986, 17, 567-594. [CrossRef]

118. Yeung, A.C.; Kreutzweiser, D.P.; Richardson, J.S. Stronger effects of litter origin on the processing of conifer than broadleaf leaves: A test of home-field advantage of stream litter breakdown. Freshwat. Biol. 2019, 64, 1755-1768. [CrossRef]

119. Fugère, V.; Lostchuck, E.; Chapman, L.J. Litter decomposition in Afrotropical streams: Effects of land use, home-field advantage, and terrestrial herbivory. Freshwat. Sci. 2020, 39, 497-507. [CrossRef]

120. Reich, P.B.; Oleksyn, J. Global patterns of plant leaf $\mathrm{N}$ and $\mathrm{P}$ in relation to temperature and latitude. Proc. Nat. Acad. Sci. USA 2004, 101, 11001-11006. [CrossRef]

121. Gong, S.; Guo, R.; Zhang, T.; Guo, J. Warming and nitrogen addition increase litter decomposition in a temperate meadow ecosystem. PLoS ONE 2015, 10, e0116013. [CrossRef] 
122. Pozo, J.; Casas, J.; Menéndez, M.; Mollá, S.; Arostegui, I.; Basaguren, A.; Casado, C.; Desclas, E.; Gracía-Avilés, J.; González, J.M.; et al. Leaf-litter decomposition in headwater streams: A comparison of the process among four climatic regions. J. N. Am. Benthol. Soc. 2011, 30, 935-950. [CrossRef]

123. Webb, J.R.; Pearce, N.J.; Painter, K.J.; Yates, A.G. Hierarchical variation in cellulose decomposition in least-disturbed reference streams: A multi-season study using the cotton strip assay. Landsc. Ecol. 2019, 34, 2353-2369. [CrossRef]

124. Ferreira, V.; Canhoto, C. Effect of experimental and seasonal warming on litter decomposition in a temperate stream. Aquat. Sci. 2014, 76, 155-163. [CrossRef]

125. Langhans, S.D.; Tiegs, S.D.; Gessner, M.O.; Tockner, K. Leaf-decomposition heterogeneity across a riverine floodplain mosaic. Aquat. Sci. 2008, 70, 337-346. [CrossRef]

126. Martínez, A.; Basaguren, A.; Larrañaga, A.; Molinero, J.; Pérez, J.; Sagarduy, M.; Pozo, J. Differences in water depth determine leaf-litter decomposition in streams: Implications on impact assessment reliability. Knowl. Manag. Aquat. Ecosyst. 2016, 417, 23. [CrossRef]

127. Sandin, L.; Verdonschot, P.F.M. Stream and river typologies-Major results and conclusions from the STAR project. In The Ecological Status of European Rivers: Evaluation and Intercalibration of Assessment Methods; Furse, M.T., Hering, D., Brabec, K., Buffagni, A., Sandin, L., Verdonschot, P.F.M., Eds.; Springer: Dordrecht, The Netherlands, 2006; pp. 33-37.

128. Tiegs, S.D.; Akinwole, P.O.; Gessner, M.O. Litter decomposition across multiple spatial scales in stream networks. Oecologia 2009, 161, 343-351. [CrossRef] [PubMed]

129. Sarkanen, K.V.; Ludwig, C.H. Lignins: Occurrence, Formation, Structure and Reactions; John Wiley and Sons: New York, NY, USA, 1971; Volume 10, pp. 228-230.

130. Díez, J.; Elosegi, A.; Chauvet, E.; Pozo, J. Breakdown of wood in the Agüera stream. Freshwat. Biol. 2002, 47, 2205-2215. [CrossRef]

131. Elosegi, A.; Díez, J.; Pozo, J. Contribution of dead wood to the carbon flux in forested streams. Earth Surf. Process. Landf. 2007, 32, 1219-1228. [CrossRef]

132. Spänhoff, B.; Meyer, E.I. Breakdown rates of wood in streams. J. N. Am. Benthol. Soc. 2004, 23, $189-197$. [CrossRef]

133. Tiegs, S.D.; Clapcott, J.E.; Griffiths, N.A.; Boulton, A.J. A standardized cotton-strip assay for measuring organic-matter decomposition in streams. Ecol. Ind. 2013, 32, 131-139. [CrossRef]

134. Vizza, C.; Zwart, J.A.; Jones, S.E.; Tiegs, S.D.; Lamberti, G.A. Landscape patterns shape wetland pond ecosystem function from glacial headwaters to ocean. Limnol. Oceanogr. 2017, 62, S207-S221. [CrossRef]

135. Costello, D.M.; Burton, G.A. Response of stream ecosystem function and structure to sediment metal: Context dependency and variation among endpoints. Elementa 2014, 2, 30. [CrossRef]

136. Griffiths, N.A.; Tiegs, S.D. Organic-matter decomposition along a temperature gradient in a forested headwater stream. Freshwat. Sci. 2016, 35, 518-533. [CrossRef]

137. Fell, S.; Carrivick, J.L.; Cauvy-Fraunie, S.C.; Crespo-Pérez, V.; Hood, E.W.; Randall, K.C.; Nicholas, K.J.M.; Dumbrell, A.J.; Tiegs, S.D.; Brown, L.E. Glacier loss accelerates fungal decomposition of river organic matter. Nat. Clim. Chang. (in press).

138. Tiegs, S.D.; Langhans, S.D.; Tockner, K.; Gessner, M.O. Cotton strips as a leaf surrogate to measure decomposition in river floodplain habitats. J. N. Am. Benthol. Soc. 2007, 26, 70-77. [CrossRef]

139. Stevenson, A. (Ed.) Oxford Dictionary of English, 3rd ed.; Oxford University Press: Oxford, UK, 2015.

140. Baker, M.A.; Dahm, C.N.; Valett, H.M. Anoxia, anaerobic metabolism biogeochemistry of the stream water-ground water interface. In Streams and Ground Waters; Jones, J.B., Mulholland, P.J., Eds.; Academic Press: San Diego, CA, USA, 2000; pp. 259-284.

141. Crenshaw, C.L.; Valett, H.M.; Webster, J.R. Effects of augmentation of coarse particulate organic matter on metabolism and nutrient retention in hyporheic sediments. Freshwat. Biol. 2002, 47, 1820-1831. [CrossRef]

142. Stanley, E.H.; Casson, N.J.; Christel, S.T.; Crawford, J.T.; Loken, L.C.; Oliver, S.K. The ecology of methane in streams and rivers: Patterns, controls, and global significance. Ecol. Monogr. 2016, 86, 146-171. [CrossRef]

143. Tank, J.L.; Rosi-Marshall, E.J.; Griffiths, N.A.; Entrekin, S.A.; Stephen, M.L. A review of allochthonous organic matter dynamics and metabolism in streams. J. N. Am. Benthol. Soci. 2010, 29, 118-146. [CrossRef]

144. Mulholland, P.J.; Fellows, C.S.; Tank, J.L.; Grimm, N.B.; Webster, J.R.; Hamilton, S.K.; Martí, E.; Ashkenas, L.; Bowden, W.B.; Dodds, W.K.; et al. Inter-biome comparison of factors controlling stream metabolism. Freshwat. Biol. 2001, 46, 1503-1517. [CrossRef] 
145. Appling, A.P.; Read, J.S.; Winslow, L.A.; Arroita, M.; Bernhardt, E.S.; Griffiths, N.A.; Hall, R.O., Jr.; Harvey, J.W.; Heffernan, J.B.; Stanley, E.H.; et al. The metabolic regimes of 356 rivers in the United States. Sci. Data 2018, 5, 180292. [CrossRef]

146. Bernhardt, E.S.; Heffernan, J.B.; Grimm, N.B.; Stanley, E.H.; Harvey, J.W.; Arroita, M.; Appling, A.P.; Cohen, M.J.; McDowell, W.H.; Hall, R.O., Jr.; et al. The metabolic regimes of flowing waters. Limnol. Oceanogr. 2018, 63, 99-118. [CrossRef]

147. Vannote, R.L.; Minshall, G.W.; Cummins, K.W.; Sedell, J.R.; Cushing, C.E. The river continuum concept. Can. J. Fish. Aquat. Sci. 1980, 37, 130-137. [CrossRef]

148. Finlay, J.C. Stream size and human influences on ecosystem production in river networks. Ecosphere 2011, 2, art87. [CrossRef]

149. Dodds, W.K.; Veach, A.M.; Ruffing, C.M.; Larson, D.M.; Fischer, J.L.; Costigan, K.H. Abiotic controls and temporal variability of river metabolism: Multiyear analyses of Mississippi and Chattahoochee River data. Freshwat. Sci. 2013, 32, 1073-1087. [CrossRef]

150. Thorp, J.H.; Thoms, M.C.; Delong, M.D. The riverine ecosystem synthesis: Biocomplexity in river networks across space and time. River Res. Appl. 2006, 22, 123-147. [CrossRef]

151. Wiley, M.J.; Osbourne, L.L.; Larimore, R.W. Longitudinal structure of an agricultural prairie river system and its relationship to current stream ecosystem theory. Can. J. Fish. Aquat. Sci. 1990, 47, 373-384. [CrossRef]

152. Young, R.G.; Huryn, A.D. Interannual variation in discharge controls ecosystem metabolism along a grassland river continuum. Can. J. Fish. Aquat. Sci. 1996, 53, 2199-2211. [CrossRef]

153. Acuña, V.; Vilches, C.; Giorgi, A. As productive and slow as a stream can be-the metabolism of a Pampean stream. J. N. Am. Benthol. Soc. 2011, 30,71-83. [CrossRef]

154. Pieterse, A.; Roos, J. Diurnal variations in the Vaal, a turbid South African river: Physical, chemical and phytoplankton biomass characteristics. Arch. Hydrobiol. 1992, 18, 21-26.

155. Fellows, C.S.; Bunn, S.E.; Sheldon, F.; Beard, N.J. Benthic metabolism in two turbid dryland rivers. Freshwat. Biol. 2009, 54, 236-253. [CrossRef]

156. Stanford, J.A.; Ward, J.V. Revisiting the serial discontinuity concept. Reg. Rivers—Res. Manag. 2001, 17, 303-310. [CrossRef]

157. Roberts, B.J.; Mulholland, P.J.; Hill, W.R. Multiple scales of temporal variability in ecosystem metabolism rates: Results from 2 years of continuous monitoring in a forested headwater stream. Ecosystems 2007, 10, 588-606. [CrossRef]

158. Uehlinger, U.; Naegeli, M.W. Ecosystem metabolism, disturbance, and stability in a prealpine gravel bed river. J. N. Am. Benthol. Soc. 1998, 17, 165-178. [CrossRef]

159. Izagirre, O.; Agirre, U.; Bermejo, M.; Pozo, J.; Elosegi, A. Environmental controls of whole-stream metabolism identified from continuous monitoring of Basque streams. J. N. Am. Benthol. Soc. 2008, 27, 252-268. [CrossRef]

160. Oconnor, B.L.; Harvey, J.W.; McPhillips, L.E. Thresholds of flow-induced bed disturbances and their effects on stream metabolism in an agricultural river. Water Resources Res. 2012, 48, 1-18. [CrossRef]

161. Acuña, V.; Giorgi, A.; Munoz, I.; Uehlinger, U.; Sabater, S. Flow extremes and benthic organic matter shape the metabolism of a headwater Mediterranean stream. Freshwat. Biol. 2004, 49, 960-971. [CrossRef]

162. Lamberti, G.A.; Ashkenas, L.R.; Gregory, S.V.; Steinman, A.D. Effects of Three Herbivores on Periphyton Communities in Laboratory Streams. J. N. Am. Benthol. Soc. 1987, 6, 92-104. [CrossRef]

163. Aristi, I.; Arroita, M.; Larrañaga, A.; Ponsatí, L.; Sabater, S.; von Schiller, D.; Elosegi, A.; Acuña, V. Flow regulation by dams affects ecosystem metabolism in Mediterranean rivers. Freshwat. Biol. 2014, 59, 1816-1829. [CrossRef]

164. Jassby, A.D.; Platt, T. Mathematical formulation of the relationship between photosynthesis and light for phytoplankton. Limnol. Oceanogr. 1976, 21, 540-547. [CrossRef]

165. Savoy, P.; Appling, A.P.; Heffernan, J.B.; Stets, E.G.; Read, J.S.; Harvey, J.W.; Bernhardt, E.S. Metabolic rhythms in flowing waters: An approach for classifying river productivity regimes. Limnol. Oceanogr. 2019, 64, 1835-1851. [CrossRef]

166. Artigas, J.; García-Berhtou, E.; Bauer, D.E.; Castro, M.I.; Cochero, J.; Colautti, D.C.; Cortelezzi, A.; Donato, J.C.; Elosegi, A.; Feijoó, C. Global pressures, specific responses: Effects of nutrient enrichment in streams from different biomes. Environ. Res. Lett. 2013, 8, 014002. [CrossRef] 
167. Acuña, V.; Wolf, A.; Uehlinger, U.; Tockner, K. Temperature dependence of stream benthic respiration in an Alpine river network under global warming. Freshwat. Biol. 2008, 53, 2076-2088. [CrossRef]

168. Demars, B.O.L.; Manson, J.R.; Olafsson, J.S.; Gislason, G.M.; Gudmundsdottir, R.; Woodward, G.; Reiss, J.; Pichler, D.E.; Rasmussen, J.J.; Friberg, N. Temperature and the metabolic balance of streams. Freshwat. Biol. 2011, 56, 1106-1121. [CrossRef]

169. Kominoski, J.S.; Rosemond, A.D.; Benstead, J.P.; Gulis, V.; Manning, D.W.P. Experimental nitrogen and phosphorus additions increase rates of stream ecosystem respiration and carbon loss. Limnol. Oceanogr. 2018, 63, 22-36. [CrossRef]

170. Hall, R.O., Jr.; Beaulieu, J.J. Estimating autotrophic respiration in streams using daily metabolism data. Freshwat. Sci. 2013, 32, 507-516. [CrossRef]

171. Perkins, D.M.; Yvon-Durocher, G.; Demars, B.O.L.; Reiss, J.; Pichler, D.E.; Friberg, N.; Trimmer, M.; Woodward, G. Consistent temperature dependence of respiration across ecosystems contrasting in thermal history. Glob. Change Biol. 2012, 18, 1300-1311. [CrossRef]

172. Song, C.; Dodds, W.K.; Rüegg, J.; Argerich, A.; Baker, C.L.; Bowden, W.B.; Douglas, M.M.; Farrell, K.J.; Flinn, M.B.; Garcia, E.A.; et al. Continental-scale decrease in net primary productivity in streams due to climate warming. Nat. Geosci. 2018, 11,415-420. [CrossRef]

173. Arroita, M.; Elosegi, A.; Hall, R.O., Jr. Twenty years of daily metabolism show riverine recovery following sewage abatement. Limnol. Oceanog. 2019, 64, S77-S92. [CrossRef]

174. Aristi, I.; von Schiller, D.; Arroita, M.; Barceló, D.; Ponsatí, L.; García-Galán, M.J.; Sabater, S.; Elosegi, A.; Acuña, V. Mixed effects of effluents from a wastewater treatment plant on river ecosystem metabolism: Subsidy or stress? Freshwat. Biol. 2015, 60, 1398-1410. [CrossRef]

175. Gucker, B.; Pusch, M.T. Regulation of nutrient uptake in eutrophic lowland streams. Limnol. Oceanogr. 2006, 51, 1443-1453. [CrossRef]

176. McTammany, M.E.; Benfield, E.F.; Webster, J.R. Recovery of stream ecosystem metabolism from historical agriculture. J. N. Am. Benthol. Soc. 2007, 26, 532-545. [CrossRef]

177. Griffiths, N.A.; Tank, J.L.; Royer, T.V.; Roley, S.S.; Rosi-Marshall, E.J.; Whiles, M.R.; Beaulieu, J.J.; Johnson, L.T. Agricultural land use alters the seasonality and magnitude of stream metabolism. Limnol. Oceanogr. 2013, 58, 1513-1529. [CrossRef]

178. Roley, S.S.; Tank, J.L.; Stephen, M.L.; Johnson, L.T.; Beaulieu, J.J.; Witter, J.D. Floodplain restoration enhances denitrification and reach-scale nitrogen removal in an agricultural stream. Ecol. Appl. 2012, 22, 281-297. [CrossRef] [PubMed]

179. Hope, A.J.; McDowell, W.H.; Wollheim, W.M. Ecosystem metabolism and nutrient uptake in an urban, piped headwater stream. Biogeochemistry 2014, 121, 167-187. [CrossRef]

180. Hall, R.O., Jr.; Yackulic, C.B.; Kennedy, T.A.; Yard, M.D.; Rosi-Marshall, E.J.; Voichick, N.; Behn, K.E. Turbidity, light, temperature, and hydropeaking control primary productivity in the Colorado River, Grand Canyon. Limnol. Oceanogr. 2015, 60, 512-526. [CrossRef]

181. Bernot, M.J.; Sobota, D.J.; Hall, R.O., Jr.; Mulholland, P.J.; Dodds, W.K.; Webster, J.R.; Tank, J.L.; Ashkennas, L.R.; Cooper, L.W.; Dahm, C.N.; et al. Inter-regional comparison of land-use effects on stream metabolism. Freshwat. Biol. 2010, 55, 1874-1890. [CrossRef]

182. Acuña, V.; Muñoz, I.; Giorgi, A.; Omella, M.; Sabater, F.; Sabater, S. Drought and postdrought recovery cycles in an intermittent Mediterranean stream: Structural and functional aspects. J. N. Am. Benthol. Soc. 2005, 24, 919-933. [CrossRef]

183. Gutiérrez-Cánovas, C.; Velasco, J.; Millán, A. Effects of dilution stress on the functioning of a saline Mediterranean stream. Hydrobiologia 2009, 619, 119-132. [CrossRef]

184. Traister, E.M.; McDowell, W.H.; Kram, P.; Fottova, D.; Kolarikova, K. Persistent effects of acidification on stream ecosystem structure and function. Freshwat. Sci. 2013, 32, 586-596. [CrossRef]

185. Young, R.G.; Huryn, A.D. Effects of land-use on stream metabolism and organic matter turnover. Ecol. Appl. 1999, 9, 1359-1376. [CrossRef]

186. Francoeur, S.N.; Biggs, B.J.F. Short-term effects of elevated velocity and sediment abrasion on benthic algal communities. Hydrobiologia 2006, 561, 59-69. [CrossRef]

187. Matthaei, C.D.; Piggott, J.J.; Townsend, C.R. Multiple stressors in agricultural streams: Interactions among sediment addition, nutrient enrichment and water abstraction. J. Appl. Ecol. 2010, 47, 639-649. [CrossRef] 
188. Perry, W.B.; Stanford, J.A. Algal growth stimulus by phosphorus in Flathead Lake, Montana, sediments (Selenastrum capricornutum). Northwest Sci. 1982, 56, 48-52.

189. Dent, L.; Vick, D.; Abraham, K.; Schoenholtz, S.; Johnson, S. Summer temperature patterns in headwater streams of the Oregon Coast Range. J. Am. Water Res. Ass. 2008, 44, 803-813. [CrossRef]

190. Arismendi, I.; Safeeq, M.; Dunham, J.B.; Johnson, S.L. Can air temperature be used to project influences of climate change on stream temperature? Environ. Res. Lett. 2014, 9, 084015. [CrossRef]

191. Whitton, B.A.; Ellwood, N.T.W.; Kawecka, B. Biology of the freshwater diatom Didymosphenia: A review. Hydrobiologia 2009, 630, 1-37. [CrossRef]

192. Aristi, I.; Clapcott, J.E.; Acuña, V.; Elosegi, A.; Mills, H.; Wood, S.A.; Young, R.G. Forestry affects the abundance of Phormidium-dominated biofilms and the functioning of a New Zealand river ecosystem. Marine Freshwat. Res. 2017, 68, 1741-1751. [CrossRef]

193. Brack, W.; Altenburger, R.; Schüürmann, G.; Krauss, M.; López Herráez, D.; van Gils, J.; Slobodnik, J.; Munthe, J.; Gawlok, B.M.; van Wezel, A.; et al. The SOLUTIONS project: Challenges and responses for present and future emerging pollutants in land and water resources management. Sci. Total Environ. 2015, 503-504, 22-31. [CrossRef]

194. Aristi, I.; Casellas, M.; Elosegi, A.; Insa, S.; Petrovic, M.; Sabater, S.; Acuña, V. Nutrients versus emerging contaminants-Or a dynamic match between subsidy and stress effects on stream biofilms. Environ. Poll. 2016, 212, 208-215. [CrossRef]

195. Sabater, S.; Elosegi, A.; Ludwig, R. Multiple Stressors in River Ecosystems. Status, impacts and Prospects for the Future; Elsevier: Amsterdam, The Netherlands, 2019.

196. Blaszczak, J.R.; Delesantro, J.M.; Urban, D.L.; Doyle, M.W.; Bernhardt, E.S. Scoured or suffocated: Urban stream ecosystems oscillate between hydrologic and dissolved oxygen extremes. Limnol. Oceanogr. 2019, 64, 877-894. [CrossRef]

197. Odum, H.T. Primary production in flowing waters. Limnol. Oceanogr. 1956, 1, 102-117. [CrossRef]

198. Hall, R.O., Jr.; Hotchkiss, E.R. Stream metabolism. In Methods in Stream Ecology; Lamberti, G., Hauer, F.R., Eds.; Academic Press: Cambridge, MA, USA, 2017; Volume 2, pp. 219-233.

199. Demars, B.O.L.; Thompson, J.; Manson, J.R. Stream metabolism and the open diel oxygen method: Principles, practice, and perspectives. Limnol. Oceanogr. Meth. 2015, 13, 356-374. [CrossRef]

200. Elosegi, A.; Gessner, M.; Young, R.G. River doctors: Learning from medicine to enhance ecosystem management. Sci. Total Environ. 2017, 595, 294-302. [CrossRef] [PubMed]

201. Hornberger, G.M.; Kelly, M.G. Atmospheric reaeration in a river using productivity analysis. J. Environ. Engin. Div. 1975, 101, 729-739.

202. Holtgrieve, G.W.; Schindler, D.E.; Branch, T.A.; A'mar, Z.T. Simultaneous quantification of aquatic ecosystem metabolism and reaeration using a Bayesian statistical model of oxygen dynamics. Limnol. Oceanogr. 2010, 55, 1047-1063. [CrossRef]

203. Izagirre, O.; Bermejo, M.; Pozo, J.; Elosegi, A. RIVERMET: An excel-based tool to calculate river metabolism from diel oxygen—concentration curves. Environ. Model. Softw. 2007, 22, 24-32. [CrossRef]

204. Grace, M.R.; Giling, D.P.; Hladyz, S.; Caron, V.; Thompson, R.M.; Mac Nally, R. Fast processing of diel oxygen curves: Estimating stream metabolism with BASE (BAyesian Single-station Estimation). Limnol. Oceanogr. 2015, 13, 103-114. [CrossRef]

205. Appling, A.P.; Hall, R.O., Jr.; Yackulic, C.B.; Arroita, M. Overcoming equifinality: Leveraging long time series for stream metabolism estimation. J. Geophysical Res. Biogeosci. 2018, 123, 624-645. [CrossRef]

206. Giling, D.P.; Grace, M.R.; Mac Nally, R.; Thompson, R.M. The influence of native replanting on stream ecosystem metabolism in a degraded landscape: Can a little vegetation go a long way? Freshwat. Biol. 2013, 58, 2601-2613. [CrossRef]

207. Doehring, K.; Clapcott, J.E.; Young, R.G. Assessing the functional response to streamside fencing of pastoral Waikato streams, New Zealand. Water 2019, 11, 1347. [CrossRef]

208. Collier, K.J.; Clapcott, J.E.; Duggan, I.D.; Hamilton, D.P.; Hamer, M.; Young, R.G. Spatial variation of structural and functional indicators in a large New Zealand river. River Res. Appl. 2013, 29, 1277-1290. [CrossRef]

209. Clapcott, J.E.; Young, R.G.; Neale, M.W.; Doehring, K.; Barmuta, L.A. Land use affects temporal variation in stream metabolism. Freshwat. Sci. 2016, 35, 1164-1175. [CrossRef] 
210. Bunn, S.E.; Abal, E.G.; Smith, M.J.; Choy, S.C.; Fellows, C.S.; Harch, B.D.; Kennard, M.J.; Sheldon, F. Integration of science and monitoring of river ecosystem health to guide investments in catchment protection and rehabilitation. Freshwat. Biol. 2010, 55, 223-240. [CrossRef]

211. Fellows, C.S.; Clapcott, J.E.; Udy, J.W.; Bunn, S.E.; Harch, B.D.; Smith, M.J.; Davies, P.M. Benthic metabolism as an indicator of stream ecosystem health. Hydrobiologia 2006, 572,71-87. [CrossRef]

212. Haddaway, N.R.; Bernes, C.; Jonsson, B.G.; Hedlund, K. The benefits of systematic mapping to evidence-based environmental management. Ambio 2016, 45, 613-620. [CrossRef] [PubMed]

213. Young, R.G.; Huryn, A.D.; Townsend, C.R. Effects of agricultural development on processing of tussock leaf litter in high country New Zealand streams. Freshwat. Biol. 1994, 32, 413-427. [CrossRef]

214. Pascoal, C.; Cássio, F.; Gomes, P. Leaf breakdown rates: A measure of water quality? Internat. Rev. Hydrobiol. 2001, 86, 407-416. [CrossRef]

215. Houser, J.N.; Mulholland, P.J.; Maloney, K.O. Catchment disturbance and stream metabolism: Patterns in ecosystem respiration and gross primary production along a gradient of upland soil and vegetation disturbance. J. N. Am. Benthol. Soc. 2005, 24, 538-552. [CrossRef]

216. Johnson, K.S.; Thompson, P.C.; Gromen, L.; Bowman, J. Use of leaf litter breakdown and macroinvertebrates to evaluate gradient of recovery in an acid mine impacted stream remediated with an active alkaline doser. Environ. Monit. Assess. 2014, 186, 4111-4127. [CrossRef]

217. Frainer, A.; Polvi, L.E.; Jansson, R.; McKie, B.G. Enhanced ecosystem functioning following stream restoration: The roles of habitat heterogeneity and invertebrate species traits. J. Appl. Ecol. 2018, 55, 377-385. [CrossRef]

218. Dodds, W.K.; Bruckerhoff, L.; Batzer, D.; Schechner, A.; Pennock, C.; Renner, E.; Tromboni, F.; Bigham, K.; Grieger, S. The freshwater biome gradient framework: Predicting macroscale properties based on latitude, altitude, and precipitation. Ecosphere 2019, 10, e02786. [CrossRef]

219. Seena, S.; Bärlocher, F.; Sobral, O.; Gessner, M.O.; Dudgeon, D.; McKie, B.G.; Cahuvet, E.; Boyero, L.; Ferreira, V.; Frainer, A.; et al. Biodiversity of leaf litter fungi in streams along a latitudinal gradient. Sci. Total Environ. 2019, 661, 306-315. [CrossRef]

220. Boyero, L.; Pearson, R.G.; Dudgeon, D.; Graça, M.A.S.; Gessner, M.O.; Albariño, R.J.; Ferreira, V.; Yule, C.M.; Boulton, A.J.; Arunachalam, M.; et al. Global distribution of a key trophic guild contrasts with common latitudinal diversity patterns. Ecology 2011, 92, 1839-1848. [CrossRef] [PubMed]

221. Wallace, J.B.; Eggert, S.L.; Meyer, J.L.; Webster, J.R. Multiple trophic levels of a forest stream linked to terrestrial litter inputs. Science 1997, 277, 102-104. [CrossRef]

222. Abelho, M. From litterfall to breakdown in streams: A review. Sci. World J. 2001, 1, 656-680. [CrossRef] [PubMed]

223. Baldy, V.; Chauvet, E.; Charcosset, J.Y.; Gessner, M.O. Microbial dynamics associated with leaves decomposing in the mainstem and floodplain pond of a large river. Aquat. Microb. Ecol. 2002, 28, 25-36. [CrossRef]

224. Chauvet, E. Leaf litter decomposition in large rivers: The case of the River Garonne. Limnetica 1997, 13, 65-70.

225. Molinero, J.; Pozo, J. Impact of a eucalyptus (Eucalyptus globulus Labill.) plantation on the nutrient content and dynamics of coarse particulate organic matter (CPOM) in a small stream. Hydrobiologia 2004, 528, 143-165. [CrossRef]

226. Molinero, J. Seasonality and composition of benthic coarse particulate organic matter in two coastal tropical streams with different land uses. Hydrobiologia 2019, 838, 29-43. [CrossRef]

227. Latter, P.M.; Walton, D.W.H. The cotton strip assay for cellulose decomposition in soil: History of the assay and development. In Cotton Strip Assay: An Index of Decomposition in Soils; Harrison, A.F., Latter, P.M., Walton, D.W.H., Eds.; Institute of Terrestrial Ecology, Merlewood Research Station, Grange-over-Sands: Cumbria, UK, 1988; pp. 7-10.

228. Boulton, A.J.; Quinn, J.M. A simple and versatile technique for assessing cellulose decomposition potential in floodplain and riverine sediments. Arch. Hydrobiol. 2000, 150, 133-151. [CrossRef]

229. Mlambo, M.C.; Paavola, R.; Fritze, H.; Louhi, P.; Muotka, T. Leaf litter decomposition and decomposer communities in streams affected by intensive forest biomass removal. Ecol. Ind. 2019, 101, 364-372. [CrossRef]

230. Swan, C.M.; Palmer, M.A. Leaf diversity alters litter breakdown in a Piedmont stream. J. N. Am. Benthol. Soc. 2004, 23, 15-28. [CrossRef]

231. Aristegi, L.; Izagirre, O.; Elosegi, A. Comparison of several methods to calculate reareation in streams and their effects on metabolism estimations. Hydrobiologia 2009, 635, 113-124. [CrossRef] 
232. Stanaway, D.; Haggerty, R.; Benner, S.; Flores, A.; Feris, K. Persistent metal contamination limits lotic ecosystem heterotrophic metabolism after more than 100 years of exposure: A novel application of the resazurin resorufin smart tracer. Environ. Sci. Technol. 2012, 46, 9862-9871. [CrossRef]

233. Hill, B.H.; Elonen, C.M.; Herlihy, A.T.; Jicha, T.M.; Mitchell, R.M. A synoptic survey of microbial respiration, organic matter decomposition, and carbon efflux in US streams and rivers. Limnol. Oceanogr. 2017, 62, S147-S159. [CrossRef]

234. Bergfur, J. Seasonal variation in leaf-litter breakdown in nine boreal streams: Implications for assessing functional integrity. Fund. Appl. Limnol./Arch. Hydrobiol. 2007, 169, 319-329. [CrossRef]

235. Bergfur, J.; Johnson, R.K.; Sandin, L.; Goedkoop, W. Assessing the ecological integrity of boreal streams: A comparison of functional and structural responses. Fund. Appl. Limnol./Arch. Hydrobiol. 2007, 168, 113-125. [CrossRef]

236. Collier, K.J.; Clapcott, J.E.; Hamer, M.P.; Young, R.G. Extent estimates and land cover relationships for functional indicators in non-wadeable rivers. Ecol. Ind. 2013, 34, 53-59. [CrossRef]

237. Estevez, E.; Rodríguez-Castillo, T.; Álvarez-Cabria, M.; Peñas, F.J.; González-Ferreras, A.M.; Lezcano, M.; Barquín, J. Analysis of structural and functional indicators for assessing the health state of mountain streams. Ecol. Ind. 2017, 72, 553-564. [CrossRef]

238. Northington, R.M.; Benfield, E.F.; Schoenholtz, S.H.; Timpano, A.J.; Webster, J.R.; Zipper, C. An assessment of structural attributes and ecosystem function in restored Virginia coalfield streams. Hydrobiologia 2011, 671, 51-63. [CrossRef]

239. DaSilva, A.; Xu, Y.J.; Ice, G.; Beebe, J.; Stich, R. Effects of timber harvesting with best management practices on ecosystem metabolism of a low gradient stream on the United States Gulf Coastal Plain. Water 2013, 5 , 747-766. [CrossRef]

240. Aldridge, K.T.; Brookes, J.D.; Ganf, G.G. Rehabilitation of stream ecosystem functions through the reintroduction of coarse particulate organic matter. Rest. Ecol. 2009, 17, 97-106. [CrossRef]

241. Kupilas, B.; Hering, D.; Lorenz, A.W.; Knuth, C.; Gucker, B. Hydromorphological restoration stimulates river ecosystem metabolism. Biogeosciences 2017, 14, 1989-2002. [CrossRef]

242. Blersch, S.S.; Blersch, D.M.; Atkinson, J.F. Metabolic variance: A metric to detect shifts in stream ecosystem function as a result of stream restoration. J. Am. Water Res. Ass. 2019, 55, 608-621. [CrossRef]

243. Bunn, S.E.; Davies, P.M. Biological processes in running waters and their implications for the assessment of ecological integrity. In Assessing the Ecological Integrity of Running Waters. Developments in Hydrobiology; Jungwirth, M., Muhar, S., Schmutz, S., Eds.; Springer: Dordrecht, The Netherlands, 2000; Volume 149, pp. 61-70. [CrossRef]

244. Palmer, M.A.; Febria, C.M. The heartbeat of ecosystems. Science 2012, 336, 1393-1394. [CrossRef] [PubMed]

245. Young, R.G.; Clapcott, J.E. Temporal Variability in Ecosystem Metabolism of Rivers in the Manawatu-Whanganui Region-Updated; Prepared for Horizons Regional Council; Cawthron Report No. 1791; Cawthron Institute: Nelson, New Zealand, 2010; p. 25.

246. Doehring, K.; Young, R.G. Seasonal Patterns in Ecosystem Metabolism of Rivers in the Auckland Region 2003-2009; Prepared for Auckland Regional Council; Cawthron Report No. 1795; Cawthron Institute: Nelson, New Zealand, 2010; p. 23.

247. Young, R.G.; Doehring, K.A.M.; James, T. River Water Quality in Tasman District 2010; Prepared for Tasman District Council; Cawthron Report No. 1893; Cawthron Institute: Nelson, New Zealand, 2010; p. 165.

248. Clapcott, J.E.; Doehring, K. Temporal Variation in Ecosystem Metabolism in Relation to Water Quality in the Piako River; Prepared for Waikato Regional Council; Cawthron Report No. 2550; Cawthron Institute: Nelson, New Zealand, 2014; p. 32.

249. Parkyn, S.; Collier, K.; Clapcott, J.; David, B.; Davies-Colley, R.; Matheson, F.; Quinn, J.; Shaw, W.; Storey, R. The Restoration Indicators Toolkit: Indicators for Monitoring the Ecological Success of Stream Restoration; NIWA: Hamilton, NY, USA, 2010.

250. Young, R.G. A Trial of Wood Decomposition Rates as an Ecological Assessment Tool in Large Rivers; Prepared for West Coast Regional Council; Cawthron Report No. 1339; Cawthron Institute: Nelson, New Zealand, 2007; p. 6.

251. Collier, K.J. Wood decay rates and macroinvertebrate community structure along contrasting human pressure gradients (Waikato, New Zealand). N. Z. J. Mar. Freshwat. Res. 2014, 48, 97-111. [CrossRef] 
252. Colas, F.; Baudoin, J.M.; Gob, F.; Tamisier, V.; Valette, L.; Kreutzenberger, K.; Lambrigot, D.; Chauvet, E. Scale dependency in the hydromorphological control of a stream ecosystem functioning. Water Res. 2017, 115, 60-73. [CrossRef]

253. Thompson, M.S.; Bankier, C.; Bell, T.; Dumbrell, A.J.; Gray, C.; Ledger, M.E.; Lehmann, K.; McKew, B.A.; Sayer, C.D.; Shelley, F.; et al. Gene-to-ecosystem impacts of a catastrophic pesticide spill: Testing a multilevel bioassessment approach in a river ecosystem. Freshwat. Biol. 2016, 61, 2037-2050. [CrossRef]

254. Carballeira, C.; Villares, R.; Mata-Rivas, B.; Carballeira, A. The cotton-strip assay as an environmental surveillance tool for ecological integrity assessment of rivers affected by WWTP effluents. Water Res. 2020, 169, 115247. [CrossRef]

255. Aristi, I.; Díez, J.R.; Larrañaga, A.; Navarro-Ortega, A.; Barceló, D.; Elosegi, A. Assessing the effects of multiple stressors on the functioning of Mediterranean rivers using poplar wood breakdown. Sci. Total Environ. 2012, 440, 272-279. [CrossRef]

256. Brosed, M.; Lamothe, S.; Chauvet, E. Litter breakdown for ecosystem integrity assessment also applies to streams affected by pesticides. Hydrobiologia 2016, 773, 87-102. [CrossRef]

257. Jabiol, J.; Colas, F.; Guérold, F. Cotton-strip assays: Let's move on to eco-friendly biomonitoring! Water Res. 2020, 170, 115295. [CrossRef]

258. Lecerf, A.; Chauvet, E. Diversity and functions of leaf-decaying fungi in human-altered streams. Freshwat. Biol. 2008, 53, 1658-1672. [CrossRef]

259. Imberger, S.J.; Thompson, R.M.; Grace, M.R. Searching for effective indicators of ecosystem function in urban streams: Assessing cellulose decomposition potential. Freshwat. Biol. 2010, 55, 2089-2106. [CrossRef]

260. Noel, L.; Bärlocher, F.; Culp, J.M.; Seena, S. Nutrient enrichment and flow regulation impair structure and function of a large river as revealed by aquatic hyphomycete species richness, biomass, and decomposition rates. Freshwat. Sci. 2016, 35, 1148-1163. [CrossRef]

261. Hladyz, S.; Tiegs, S.D.; Gessner, M.O.; Giller, P.S.; Risnoveanu, G.; Preda, E.; Nistorescu, M.; Schindler, M.; Woodward, G. Leaf-litter breakdown in pasture and deciduous woodland streams: A comparison among three European regions. Freshwat. Biol. 2010, 55, 1916-1929. [CrossRef]

262. Fritz, K.M.; Fulton, S.; Johnson, B.R.; Barton, C.D.; Jack, J.D.; Word, D.A.; Burke, R.A. An assessment of cellulose filters as a standardized material for measuring litter breakdown in headwater streams. Ecohydrology 2011, 4, 469-476. [CrossRef]

263. Krenz, R.J.; Schoenholtz, S.H.; Zipper, C.E. Riparian subsidies and hierarchical effects of ecosystem structure on leaf breakdown in Appalachian coalfield constructed streams. Ecol. Eng. 2016, 97, 389-399. [CrossRef]

264. Collins, S.J.; Bellingham, L.; Mitchell, G.W.; Fahrig, L. Life in the slow drain: Landscape structure affects farm ditch water quality. Sci. Total Environ. 2019, 656, 1157-1167. [CrossRef]

265. Spänhoff, B.; Bischof, R.; Bohme, A.; Lorenz, S.; Neumeister, K.; Nothlich, A.; Kusel, K. Assessing the impact of effluents from a modern wastewater treatment plant on breakdown of coarse particulate organic matter and benthic macroinvertebrates in a lowland river. Wat. Air Soil Poll. 2007, 180, 119-129. [CrossRef]

266. Silva-Junior, E.F.; Moulton, T.P. Ecosystem functioning and community structure as indicators for assessing environmental impacts: Leaf processing and macroinvertebrates in Atlantic forest streams. Internat. Rev. Hydrobiol. 2011, 96, 656-666. [CrossRef]

267. Silva-Junior, E.F.; Moulton, T.P.; Boëchat, I.G.; Gücker, B. Leaf decomposition and ecosystem metabolism as functional indicators of land use impacts on tropical streams. Ecol. Ind. 2014, 36, 195-204. [CrossRef]

268. Principe, R.E.; Marquez, J.A.; Martina, L.C.; Jobbagy, E.G.; Albariño, R.J. Pine afforestation changes more strongly community structure than ecosystem functioning in grassland mountain streams. Ecol. Ind. 2015, 57, 366-375. [CrossRef]

269. Simon, K.S.; Simon, M.A.; Benfield, E.F. Variation in ecosystem function in Appalachian streams along an acidity gradient. Ecol. Appl. 2009, 19, 1147-1160. [CrossRef] [PubMed]

270. Clapcott, J.E.; Barmuta, L.A. Forest clearance increases metabolism and organic matter processes in small headwater streams. J. N. Am. Benthol. Soc. 2010, 29, 546-561. [CrossRef]

271. Clapcott, J.E.; Collier, K.J.; Death, R.G.; Goodwin, E.O.; Harding, J.S.; Kelly, D.; Leathwick, J.R.; Young, R.G. Quantifying relationships between land-use gradients and structural and functional indicators of stream ecological integrity. Freshwat. Biol. 2012, 57, 74-90. [CrossRef] 
272. Wagenhoff, A.; Liess, A.; Pastor, A.; Clapcott, J.E.; Goodwin, E.O.; Young, R.G. Thresholds in ecosystem structural and functional responses to agricultural stressors can inform limit setting in streams. Freshwat. Sci. 2017, 36, 178-194. [CrossRef]

273. Martin, E.J.; Doering, M.; Robinson, C.T. Ecological assessment of a sediment by-pass tunnel on a receiving stream in Switzerland. River Res. Appl. 2017, 33, 925-936. [CrossRef]

274. Huang, W.; Liu, X.B.; Peng, W.Q.; Wu, L.X.; Yano, S.; Zhang, J.M.; Zhao, F. Periphyton and ecosystem metabolism as indicators of river ecosystem response to environmental flow restoration in a flow-reduced river. Ecol. Ind. 2018, 92, 394-401. [CrossRef]

275. Townsend, S.A.; Webster, I.T.; Burford, M.A.; Schult, J. Effects of autotrophic biomass and composition on photosynthesis, respiration and light utilisation efficiency for a tropical savanna river. Mar. Freshwat. Res. 2018, 69, 1279-1289. [CrossRef]

276. Sabater, S.; Bregoli, F.; Acuña, V.; Barceló, D.; Elosegi, A.; Ginebreda, A.; Marcé, R.; Muñoz, I.; Sabater-Liesa, L.; Ferreira, V. Effects of human-driven water stress on river ecosystems: A meta-analysis. Sci. Rep. 2018, 8, 11462. [CrossRef]

277. Garnier, J.; Billen, G. Production vs. respiration in river systems: An indicator of an "ecological status". Sci. Total Environ. 2007, 375, 110-124. [CrossRef]

278. Clapcott, J.E.; Young, R.G.; Goodwin, E.O.; Leathwick, J.R. Exploring the response of functional indicators of stream health to land-use gradients. Freshwat. Biol. 2010, 55, 2181-2199. [CrossRef]

279. Almeida, G.H.; Boechat, I.G.; Gucker, B. Assessment of stream ecosystem health based on oxygen metabolism: Which sensor to use? Ecol. Eng. 2014, 69, 134-138. [CrossRef]

280. Bott, T.L.; Newbold, J.D. Ecosystem metabolism and nutrient uptake in Peruvian headwater streams. Internat. Rev. Hydrobiol. 2013, 98, 117-131. [CrossRef]

281. Lebkuecher, J.G.; Rainey, S.M.; Williams, C.B.; Hall, A.J. Impacts of non-point source pollution on the structure of diatom assemblages, whole-stream oxygen metabolism, and growth of Selenastrum capricornutum in the Red river watershed of north-central Tennessee. Castanea 2011, 76, 279-292. [CrossRef]

282. Hornbach, D.; Hove, M.; Agata, M.; Albright, E.; Cavazos, E.; Friedman, C.; Jay, K.; Johnson, E.; Johnson, K.; Staudenmaier, A. Ecosystem structure and function in two branches of an eastern Minnesota, USA, trout stream. J. Freshwat. Ecol. 2016, 31, 487-507. [CrossRef]

283. Feio, M.J.; Alves, T.; Boavida, M.; Medeiros, A.; Graça, M.A.S. Functional indicators of stream health: A river-basin approach. Freshwat. Biol. 2010, 55, 1050-1065. [CrossRef]

284. Usher, R.L.; Wood, J.; Bumpers, P.M.; Wenger, S.J.; Rosemond, A.D. Streamwater nutrients stimulate respiration and breakdown of standardized detrital substrates across a landscape gradient: Effects of nitrogen, phosphorus, and carbon quality. Freshwat. Sci. 2020, 39, 101-114. [CrossRef]

285. Nelson, C.E.; Bennett, D.M.; Cardinale, B.J. Consistency and sensitivity of stream periphyton community structural and functional responses to nutrient enrichment. Ecol. Appl. 2017, 23, 159-173. [CrossRef]

286. Bergfur, J.; Johnson, R.K.; Sandin, L.; Goedkoop, W.; Nygren, K. Effects of nutrient enrichment on boreal streams: Invertebrates, fungi and leaf-litter breakdown. Freshwat. Biol. 2007, 52, 1618-1633. [CrossRef]

287. Cortes, R.; Hughes, S.; Coimbra, A.; Monteiro, S.; Pereira, V.; Lopes, M.; Pereira, S.; Pinto, A.; Sampaio, A.; Santos, C.; et al. A multiple index integrating different levels of organization. Ecotoxicol. Environ. Saf. 2016, 132, 270-278. [CrossRef]

288. Death, R.G.; Dewson, Z.S.; James, A.B. Is structure or function a better measure of the effects of water abstraction on ecosystem integrity? Freshwat. Biol. 2009, 54, 2037-2050. [CrossRef]

289. del Arco, A.I.; Ferreira, V.; Graça, M.A.S. The performance of biological indicators in assessing the ecological state of streams with varying catchment urbanisation levels in Coimbra, Portugal. Limnetica 2012, 31, 141-154.

290. Dewson, Z.S.; James, A.B.W.; Death, R.G. Stream ecosystem functioning under reduced flow conditions. Ecol. Appl. 2007, 17, 1797-1808. [CrossRef]

291. Erdozain, M.; Kidd, K.; Kreutzweiser, D.; Sibley, P. Linking stream ecosystem integrity to catchment and reach conditions in an intensively managed forest landscape. Ecosphere 2018, 9, e02278. [CrossRef]

292. Friberg, N. Impacts and indicators of change in lotic ecosystems. Wiley Interdiscipl. Rev. Water 2014, 1, 513-531. [CrossRef]

293. Huang, W.; Liu, X.B.; Peng, W.Q.; Ma, W.; Zhang, J.M. Quantitative response of leaf-litter decomposition rate to water abstraction in a gradient: Implications for environmental flow management. Ecohydrology 2018, 11, e1919. [CrossRef] 
294. Jinggut, T.; Yule, C.M.; Boyero, L. Stream ecosystem integrity is impaired by logging and shifting agriculture in a global megadiversity center (Sarawak, Borneo). Sci. Total Environ. 2012, 437, 83-90. [CrossRef] [PubMed]

295. Lecerf, A.; Richardson, J.S. Litter decomposition can detect effects of high and moderate levels of forest disturbance on stream condition. Forest Ecol. Manag. 2010, 259, 2433-2443. [CrossRef]

296. McTammany, M.E.; Benfield, E.F.; Webster, J.R. Effects of agriculture on wood breakdown and microbial biofilm respiration in southern Appalachian streams. Freshwat. Biol. 2008, 53, 842-854. [CrossRef]

297. Mesquita, A.; Pascoal, C.; Cássio, F. Assessing effects of eutrophication in streams based on breakdown of eucalypt leaves. Fund. Appl. Limnol./Arch. Hydrobiol. 2007, 168, 221-230. [CrossRef]

298. Mollá, S.; Casas, J.J.; Menéndez, M.; Basaguren, A.; Casado, C.; Descals, E.; González, J.-M.; Larrañaga, A.; Lusi, M.; Martínez, A.; et al. Leaf-litter breakdown as an indicator of the impacts by flow regulation in headwater streams: Responses across climatic regions. Ecol. Ind. 2017, 73, 11-22. [CrossRef]

299. Pingram, M.A.; Clapcott, J.E.; Hamer, M.P.; Atalah, J.; Ozkundakci, D. Exploring temporal and spatial variation in cotton tensile-strength loss to assess the ecosystem health of non-wadeable rivers. Ecol. Ind. 2020, 108, 105773. [CrossRef]

300. Piscart, C.; Navel, S.; Maazouzi, C.; Montuelle, B.; Cornut, J.; Mermillod-Blondin, F.; des Chatelliers, M.C.; Simon, L.; Marmonier, P. Leaf litter recycling in benthic and hyporheic layers in agricultural streams with different types of land use. Sci. Total Environ. 2011, 409, 4373-4380. [CrossRef] [PubMed]

301. Rincón, J.; Merchán, D.; Sparer, A.; Rojas, D.; Zarate, E. La descomposición de la hojarasca como herramienta para evaluar la integridad funcional de ríos altoandinos del sur del Ecuador. Rev. Biol. Trop. 2017, 65, 321-334. [CrossRef] [PubMed]

302. Tolkkinen, M.; Mykra, H.; Markkola, A.M.; Aisala, H.; Vuori, K.M.; Lumme, J.; Pirttila, A.M.; Muotka, T. Decomposer communities in human-impacted streams: Species dominance rather than richness affects leaf decomposition. J. Appl. Ecol. 2013, 50, 1142-1151. [CrossRef]

303. Vyšná, V.; Dyer, F.; Maher, W.; Norris, R. Cotton-strip decomposition rate as a river condition indicator - diel temperature range and deployment season and length also matter. Ecol. Ind. 2014, 45, 508-521. [CrossRef]

304. Yeung, A.C.; Musetta-Lambert, J.L.; Kreutzweiser, D.P.; Sibley, P.K.; Richardson, J.S. Relations of interannual differences in stream litter breakdown with discharge: Bioassessment implications. Ecosphere 2018, 9, e02423. [CrossRef]

305. Yeung, A.C.Y.; Lecerf, A.; Richardson, J.S. Assessing the long-term ecological effects of riparian management practices on headwater streams in a coastal temperate rainforest. Forest Ecol. Manag. 2017, 384, 100-109. [CrossRef]

306. Bott, T.L.; Jackson, J.K.; McTammany, M.E.; Newbold, J.D.; Rier, S.T.; Sweeney, B.W.; Battle, J.M. Abandoned coal mine drainage and its remediation: Impacts on stream ecosystem structure and function. Ecol. Appl. 2012, 22, 2144-2163. [CrossRef]

307. Brisbois, M.C.; Jamieson, R.; Gordon, R.; Stratton, G.; Madani, A. Stream ecosystem health in rural mixed land-use watersheds. J. Environ. Eng. Sci. 2008, 7, 439-452. [CrossRef]

308. Gucker, B.; Boechat, I.G.; Giani, A. Impacts of agricultural land use on ecosystem structure and whole-stream metabolism of tropical Cerrado streams. Freshwat. Biol. 2009, 54, 2069-2085. [CrossRef]

309. Larson, D.M.; Dodds, W.K.; Whiles, M.R.; Fulgoni, J.N.; Thompson, T.R. A before-and-after assessment of patch-burn grazing and riparian fencing along headwater streams. J. Appl. Ecol. 2016, 3, 1543-1553. [CrossRef]

310. Maloney, K.O.; Feminella, J.W.; Mitchell, R.M.; Miller, S.A.; Mulholland, P.J.; Houser, J.N. Landuse legacies and small streams: Identifying relationships between historical land use and contemporary stream conditions. J. N. Am. Benthol. Soc. 2008, 27, 280-294. [CrossRef]

311. Oliveira, P.C.D.; van der Geest, H.G.; Kraak, M.H.S.; Verdonschot, P.F.M. Land use affects lowland stream ecosystems through dissolved oxygen regimes. Sci. Rep. 2019, 9, 1-10.

312. Smucker, N.J.; Drerup, S.A.; Vis, M.L. Roles of benthic algae in the structure, function, and assessment of stream ecosystems affected by acid mine drainage. J. Phycol. 2014, 50, 425-436. [CrossRef]

313. von Schiller, D.; Martí, E.; Riera, J.L.; Ribot, M.; Marks, J.C.; Sabater, F. Influence of land use on stream ecosystem function in a Mediterranean catchment. Freshwat. Biol. 2008, 53, 2600-2612. [CrossRef]

314. Wolf, C.; Volker, J.; Klauer, B. The ecological status under WFD—Potentials of a supplementary functional assessment. Wasserwirtschaft 2019, 109, 22-26. [CrossRef] 
315. Yates, A.G.; Brua, R.B.; Culp, J.M.; Chambers, P.A. Multi-scaled drivers of rural prairie stream metabolism along human activity gradients. Freshwat. Biol. 2013, 58, 675-689. [CrossRef]

316. Yates, A.G.; Brua, R.B.; Culp, J.M.; Chambers, P.A.; Wassenaar, L.I. Sensitivity of structural and functional indicators depends on type and resolution of anthropogenic activities. Ecol. Ind. 2014, 45, 274-284. [CrossRef]

Publisher's Note: MDPI stays neutral with regard to jurisdictional claims in published maps and institutional affiliations.

(C) 2020 by the authors. Licensee MDPI, Basel, Switzerland. This article is an open access article distributed under the terms and conditions of the Creative Commons Attribution (CC BY) license (http://creativecommons.org/licenses/by/4.0/). 